\title{
Zinc-induced Self-association of Complement C3b and Factor $\mathrm{H}$
}

\section{IMPLICATIONS FOR INFLAMMATION AND AGE-RELATED MACULAR DEGENERATION*}

Received for publication, April 10, 2013, and in revised form, April 30, 2013 Published, JBC Papers in Press, May 9, 2013, DOI 10.1074/jbc.M113.476143

\section{Ruodan Nan (南若丹) ${ }^{\ddagger}$, Stuart Tetchner ${ }^{\ddagger}$, Elizabeth Rodriguez ${ }^{\ddagger}$, Po-Jung Pao (鮑柏蓉) ${ }^{\ddagger}$, Jayesh Gor ${ }^{\ddagger}$, Imre Lengyel ${ }^{\S 1 ，}$ and Stephen J. Perkins ${ }^{\ddagger 2}$}

From the ${ }^{\ddagger}$ Department of Structural and Molecular Biology, Darwin Building, University College London, Gower Street, London WC1E 6BT, United Kingdom and the ${ }^{\S}$ Department of Ocular Biology and Therapeutics, UCL Institute of Ophthalmology, 11-43 Bath Street, London EC1V 9EL, United Kingdom

\begin{abstract}
Background: Sub-retinal pigment epithelial deposits contain complement proteins and bioavailable zinc.
Results: Ultracentrifugation and $\mathrm{x}$-ray scattering show that $>100 \mu \mathrm{M}$ zinc induces oligomer formation in each of $\mathrm{C} 3$, C3u, and $\mathrm{C} 3 \mathrm{~b}$, in analogy to Factor $\mathrm{H}$.

Conclusion: Factor H-C3b complexes are precipitated by zinc, which inhibits complement activation.

Significance: A potential molecular mechanism for zinc-induced sub-retinal deposit formation is clarified.
\end{abstract}

The sub-retinal pigment epithelial deposits that are a hallmark of age-related macular degeneration contain both $\mathrm{C} 3 \mathrm{~b}$ and millimolar levels of zinc. $\mathrm{C} 3$ is the central protein of complement, whereas $\mathrm{C} 3 \mathrm{u}$ is formed by the spontaneous hydrolysis of the thioester bridge in C3. During activation, C3 is cleaved to form active $\mathrm{C} 3 \mathrm{~b}$, then C3b is inactivated by Factor $\mathrm{I}$ and Factor $\mathrm{H}$ to form the $\mathrm{C} 3 \mathrm{c}$ and $\mathrm{C} 3 \mathrm{~d}$ fragments. The interaction of zinc with $\mathrm{C} 3$ was quantified using analytical ultracentrifugation and $x$-ray scattering. $\mathrm{C} 3, \mathrm{C} 3 \mathrm{u}$, and C3b associated strongly in $>100 \mu \mathrm{m}$ zinc, whereas C3c and C3d showed weak association. With zinc, C3 forms soluble oligomers, whereas $\mathrm{C} 3 \mathrm{u}$ and $\mathrm{C} 3 \mathrm{~b}$ precipitate. We conclude that the $\mathrm{C} 3, \mathrm{C} 3 \mathrm{u}$, and $\mathrm{C} 3 \mathrm{~b}$ association with zinc depended on the relative positions of C3d and $\mathrm{C} 3 \mathrm{c}$ in each protein. Computational predictions showed that putative weak zinc binding sites with different capacities exist in all five proteins, in agreement with experiments. Factor $\mathrm{H}$ forms large oligomers in $>10 \mu \mathrm{M}$ zinc. In contrast to $\mathrm{C} 3 \mathrm{~b}$ or Factor $\mathrm{H}$ alone, the solubility of the central C3b-Factor $\mathrm{H}$ complex was much reduced at $60 \mu \mathrm{M}$ zinc and even more so at $>100 \mu \mathrm{M}$ zinc. The removal of the $\mathrm{C} 3 \mathrm{~b}-$ Factor $\mathrm{H}$ complex by zinc explains the reduced $\mathrm{C} 3 \mathrm{u} / \mathrm{C} 3 \mathrm{~b}$ inactivation rates by zinc. Zinc-induced precipitation may contribute to the initial development of sub-retinal pigment epithelial deposits in the retina as well as reducing the progression to advanced agerelated macular degeneration in higher risk patients.

Activation of the complement system through the classical, lectin and alternative pathways leads to the conversion of $\mathrm{C}^{3}$ to

* This work was supported by the Medical Research Council (to R. N.), the Wellcome Trust (to S. T.), and Fight For Sight (to P.-J. P.).

$\because$ Author's Choice-Final version full access.

${ }^{1}$ Supported by the Mercer Fund from Fight for Sight, the Special Trustees of Moorfields Eye Hospital, and the Bill Brown Charitable Trust.

${ }^{2}$ To whom correspondence should be addressed. Tel.: 20-7679-7048; Fax: 20-7679-7193; E-mail: s.perkins@ucl.ac.uk.

${ }^{3}$ The abbreviations used are: $\mathrm{C} 3$, complement component 3; FH, Factor $\mathrm{H}$; $A M D$, age-related macular degeneration; $S C R$, short complement regulator; RPE, retinal pigment epithelium; SRPEd, sub-RPE deposit; S, siemens; ANA, anaphylatoxin domain; CUB, complement C1r/C1s-UEGF-BMP1 domain; TED, thioester-containing domain.
C3b $(1,2)$. C3 is the most abundant complement protein in plasma (about $1.0 \mathrm{mg} / \mathrm{ml}$ or $5.3 \mu \mathrm{M}$ ) and is an acute phase protein whose concentration increases during inflammation. C3 is a member of the $\alpha 2$-macroglobulin family (3). Unactivated C3 consists of 13 domains, namely 8 macroglobulin domains MG1 to MG8, a linker domain (LNK), an anaphylatoxin domain (ANA; C3a), a complement C1r/C1s-UEGF-BMP1 domain (CUB), a thioester-containing domain (TED; C3d), and a C345C domain (Fig. 1A) (4). The spontaneous hydrolysis of the thioester bond in the TED/C3d domain leads to C3u (also known as $\mathrm{C}_{\mathrm{H} 2} \mathrm{O}$ or $\mathrm{C} 3 \mathrm{i}$ ), also with 13 domains (Fig. $1 B$ ). The formation of convertase enzyme complexes (such as those originating from complement Factor B) cleaves the ANA/C3a domain from $\mathrm{C} 3$ to form C3b. Conformational changes occur in C3b to expose the highly reactive thioester bond, which enables C3b to bind covalently to the cell surface (3). Despite structural similarities with C3b, C3u is unable to bind to surfaces due to its hydrolyzed thioester bond. When C3b is bound to the pathogen cell surface, a positive-feedback amplification leading to increased C3b production occurs (2). After C3b binding to Factor $\mathrm{H}(\mathrm{FH}), \mathrm{C} 3 \mathrm{~b}$ is cleaved by Factor I to yield inactive C3c and $\mathrm{C} 3 \mathrm{dg}$, hence regulating the amounts of active C3b $(1,2)$. FH consists of 20 short complement regulator (SCR) domains. The $\mathrm{N}$-terminal domains SCR-1/4 bind to C3b between its TED/ CUB and MG domains (5), whereas the C-terminal domains SCR-19/20 bind to the TED/C3d domain of C3b $(6,7)$. Additional C3b binding sites may occur in the middle of $\mathrm{FH}(8,9)$.

The complement proteins including $\mathrm{C} 3$ and $\mathrm{FH}$ are genetically associated with age-related macular degeneration (AMD) $(10-19)$. AMD is a leading cause of visual impairment in the elderly in the western world $(11,13)$. A hallmark of AMD is the appearance of sub-retinal pigment epithelial deposits (sRPEds) within Bruch's membrane, an extracellular matrix layer between the retinal pigment epithelium (RPE) and the choroidal microvasculature (20-22). sRPEds contain oxidized lipids, carbohydrates, and $>100$ proteins, including the complement components and trace elements $(11,23,24)$. Zinc is the second most abundant trace mineral in the human body, and ocular 


\section{Zinc-induced Oligomerization of C3}

tissues contain unusually high concentrations of zinc $(25,26)$. The secretion of zinc from zinc-rich RPE cells is elevated under oxidative stress (27). High millimolar levels of zinc were identified in sRPEds and Bruch's membrane using x-ray fluorescence, with some in a bio-available form as shown by fluorescent probes (28). Interestingly, zinc inhibits the cleavage of C3b by $\mathrm{FH}$, and $\mathrm{FH}$ aggregates in the presence of zinc $(29,30)$. Recently, both heterozygous and homozygous $\mathrm{FH}$ were each shown to self-associate indefinitely through its SCR-6/8 domains with a dissociation constant of $\sim 10 \mu \mathrm{M}(31,32)$. Although zinc has no measurable effect on Factor I, zinc was reported to bind to $\mathrm{C} 3(33,34)$. Here, to complete our studies of the $\mathrm{FH}$-zinc complexes, we have now quantified the comparative effects of zinc on the self-association of $\mathrm{C} 3, \mathrm{C} 3 \mathrm{u}, \mathrm{C} 3 \mathrm{~b}, \mathrm{C} 3 \mathrm{c}$, and $\mathrm{C} 3 \mathrm{~d}$ and its effect on the centrally important regulatory C3b-FH complex.

Zinc binding sites at protein interfaces are often formed from His, Asp, Glu, and/or Cys residues (35). A shared zinc site between two protein surfaces involves between one to three residues from each surface. To determine the extent to which surface-bound zinc causes each of C3, C3u, C3b, C3c, and C3d to self-associate, we employed analytical ultracentrifugation and synchrotron x-ray scattering (36) combined with metal binding-site predictions for these proteins (37). In comparison to our recent $\mathrm{FH}$-zinc studies $(31,32)$, we found here that the $\mathrm{C} 3, \mathrm{C} 3 \mathrm{u}$, and $\mathrm{C} 3 \mathrm{~b}$ oligomerize with a zinc concentration of $>100 \mu \mathrm{M}$ in a 10 -fold weaker manner than the zinc-induced oligomerization of FH. For the key regulatory $\mathrm{C} 3 \mathrm{~b}-\mathrm{FH}$ complex, we showed that zinc leads to the precipitation of this complex at $>100 \mu \mathrm{M}$ zinc concentrations. Our results explain why C3b cleavage by $\mathrm{FH}$ and Factor I is inhibited by zinc $(31,34)$. Molecular mechanisms are suggested for the initial formation of sRPEds that lead to AMD as well as an explanation for the role of zinc in reducing the occurrence of developing advanced AMD in high risk patients $(38,39)$.

\section{EXPERIMENTAL PROCEDURES}

Protein Purification and Concentrations-Wild-type C3 was purified from fresh human plasma by anion-exchange using a Q-Sepharose fast-flow column (Amersham Biosciences) and a Mono Q 5/50 GL column (GE Healthcare) (40). C3u was produced by incubating C3 with $200 \mathrm{~mm}$ hydrazine for $2 \mathrm{~h}$ at $37^{\circ} \mathrm{C}$ in a water bath and leaving this overnight at $4{ }^{\circ} \mathrm{C}$. C $3 \mathrm{~b}$ was produced by treating $1 \mathrm{mg} / \mathrm{ml} \mathrm{C} 3$ in HEPES buffer $(10 \mathrm{~mm}$ HEPES, $137 \mathrm{~mm} \mathrm{NaCl}, 0.5 \mathrm{~mm}$ EDTA, pH 7.4) with $10 \mu \mathrm{g} / \mathrm{ml}$ trypsin $\left(1 \% \mathrm{w} / \mathrm{w}\right.$ enzyme/substrate) for $120 \mathrm{~s}$ at $37^{\circ} \mathrm{C}$ in a water bath, then adding $40 \mu \mathrm{g} / \mathrm{ml}$ soybean trypsin inhibitor to stop cleavage before transferring onto ice. To block the free $\mathrm{SH}$ group of the $\mathrm{C} 3 \mathrm{~b}$ thioester, $20 \mathrm{~mm}$ iodoacetamide was added to the mixture, then this was incubated in the dark at $20^{\circ} \mathrm{C}$ for 30 min (5). The C3b sample was diluted in Tris buffer $(25 \mathrm{~mm}$ Tris, $140 \mathrm{~mm} \mathrm{NaCl}, 0.5 \mathrm{~mm}$ EDTA, pH 8.0), then concentrated immediately and passed through a Superose ${ }^{\text {TM }} 6$ prep grade XK 16/60 size-exclusion column. C3c was prepared by incubating outdated human plasma for 7 days at $37^{\circ} \mathrm{C}$ in a water bath, then following the same protocol for the purification of $\mathrm{C} 3$ to produce $\mathrm{C} 3 \mathrm{c}$. C3u and $\mathrm{C} 3 \mathrm{~b}$ (but not $\mathrm{C} 3$ ) were active in functional assays using Factor I and Factor H (31). Recombinant C3d with a GST tag was expressed in Escherichia coli and purified using a GSTrap FF 5-ml column (GE Healthcare) connected to a HiTrap Benzamidine FF (high sub) 1-ml column (GE Healthcare) (41). Wild-type FH was purified from outdated human plasma using monoclonal affinity chromatography (32). The absorbance coefficients for C3, C3u, C3b, C3c, C3d, and FH (1\%, $280 \mathrm{~nm}, 1 \mathrm{~cm}$ path length) were calculated from their compositions to be $9.40,9.40,9.83,9.21,13.15$, and 16.2, respectively, assuming the presence of three high mannose type oligosaccharides at Asn-63, Asn-917, and Asn-1597 in C3 (42, 43). Molecular masses were calculated from compositions to be 189.0 kDa for C3 and C3u, 179.3 kDa for C3b, 135.7 kDa for C3c, 34.6 kDa for C3d, and 154.4 kDa for FH. All proteins were passed through a size-exclusion gel filtration column to remove potential aggregates immediately before the addition of zinc, then dialyzed into HEPES buffer without EDTA. Each protein was routinely checked by SDS-PAGE before and after the ultracentrifugation and scattering experiments. Complement hemolytic activity assays were performed in triplicate using an alternative pathway kit based on the lysis of chicken erythrocytes in an agarose gel (Binding Site Group Ltd., Birmingham, UK). The diameter of the zones of lysis was measured using a jewelers' eyepiece as a measure of complement activation.

Sedimentation Velocity Data Collection and Analyses-Analytical ultracentrifugation data were obtained on two Beckman XL-I instruments equipped with AnTi50 rotors using two-sector cells with column heights of $12 \mathrm{~mm}$ at a rotor speed of $50,000 \mathrm{rpm}$. Sedimentation velocity experiments at $20^{\circ} \mathrm{C}$ were performed with $\mathrm{C} 3$ at $0.76 \mathrm{mg} / \mathrm{ml}(4.0 \mu \mathrm{M}), \mathrm{C} 3 \mathrm{u}$ at $0.87 \mathrm{mg} / \mathrm{ml}$ $(4.6 \mu \mathrm{M}), \mathrm{C} 3 \mathrm{~b}$ at $0.79 \mathrm{mg} / \mathrm{ml}(4.4 \mu \mathrm{M}), \mathrm{C} 3 \mathrm{c}$ at $0.6 \mathrm{mg} / \mathrm{ml}(4.4 \mu \mathrm{M})$, and $\mathrm{C} 3 \mathrm{~d}$ at $0.27 \mathrm{mg} / \mathrm{ml}(7.8 \mu \mathrm{M})$. Zinc titrations utilized $\mathrm{ZnSO}_{4}$ at concentrations of $0.2,6,20,60,120,200$, and $600 \mu \mathrm{M}$. The C3b-FH complex was formed by incubating C3b at $0.99 \mathrm{mg} / \mathrm{ml}$ $(5.5 \mu \mathrm{M})$ with $\mathrm{FH}$ at $0.85 \mathrm{mg} / \mathrm{ml}(5.5 \mu \mathrm{M})$ at $4{ }^{\circ} \mathrm{C}$ overnight followed by sedimentation velocity the following morning at a rotor speed of 50,000 $\mathrm{rpm}$ at $20^{\circ} \mathrm{C}$. Interference data were analyzed for $\mathrm{C} 3, \mathrm{C} 3 \mathrm{u}$, and the $\mathrm{C} 3 \mathrm{~b}-\mathrm{FH}$ complex titrated with zinc, and absorbance data were analyzed for $\mathrm{C} 3 \mathrm{~b}, \mathrm{C} 3 \mathrm{c}$, and $\mathrm{C} 3 \mathrm{~d}$ titrated with zinc using SEDFIT software (Version 14.1) (44, $45)$. The size distribution analyses $c(s)$ provided size and shape data for each species present by directly fitting the observed sedimentation boundaries to the Lamm equation using 300 interference boundaries for $\mathrm{C} 3, \mathrm{C} 3 \mathrm{u}$, and $\mathrm{C} 3 \mathrm{~b}-\mathrm{FH}$ and $25-80$ absorbance boundaries for $\mathrm{C} 3 \mathrm{~b}, \mathrm{C} 3 \mathrm{c}$, and C3d. The $c(s)$ analyses were based on a fixed resolution of 200 in which the meniscus, the bottom of the cell, the base line, and the average frictional ratio $f / f o$ were floated until the overall root mean square deviation and the fits between the observed and calculated sedimentation boundaries were satisfactory. The starting $f / f o$ values were between 1.35 to 1.4 for $\mathrm{C} 3, \mathrm{C} 3 \mathrm{u}, \mathrm{C} 3 \mathrm{~b}$, and C3c, 1.2 for C3d, and 1.78 for the $\mathrm{C} 3 \mathrm{~b}-\mathrm{FH}$ complex, Monomers and oligomers of $\mathrm{C} 3, \mathrm{C} 3 \mathrm{u}, \mathrm{C} 3 \mathrm{~b}, \mathrm{C} 3 \mathrm{c}$, and $\mathrm{C} 3 \mathrm{~d}$ were quantitated using the integration function in the $c(s)$ analyses. The integrations assumed that the signal intensities of the monomer at the lowest zinc concentrations is $100 \%$. Other details are described elsewhere $(31,46)$.

$X$-ray Scattering Data Collection and Analyses-X-ray scattering data were acquired in two beam sessions on Instrument ID02 at the European Synchrotron Radiation Facility 


\section{Zinc-induced Oligomerization of C3}

(Grenoble, France) operating with a ring energy of 6.0 gigaelectron volts in 4-bunch and 16-bunch mode to reduce the incident flux (47). The sample-detector distance was $3.0 \mathrm{~m}$, and the $\mathrm{x}$-ray wavelength was $0.0995 \mathrm{~nm}$. Potential radiation damage was eliminated by the continuous movement of the sample in a flow cell during beam exposure, the use of 10 time frames of duration between $0.1 \mathrm{~s}$ and $0.5 \mathrm{~s}$ each during each acquisition, and on-line checks for the absence of radiation damage at low Q. In the first beam session, C3 and C3u were at $0.76 \mathrm{mg} / \mathrm{ml} \mathrm{(4}$ $\mu \mathrm{M}), \mathrm{C} 3 \mathrm{~b}$ was at $0.72 \mathrm{mg} / \mathrm{ml}(4 \mu \mathrm{M})$, C3c was at $0.54 \mathrm{mg} / \mathrm{ml}(4$ $\mu \mathrm{M})$, and C3d was at $0.50 \mathrm{mg} / \mathrm{ml}(14.5 \mu \mathrm{M})$, all in HEPES buffer. In the second beam session, C3b was at $0.90 \mathrm{mg} / \mathrm{ml}(5.0 \mu \mathrm{M}), \mathrm{FH}$ was at $0.77 \mathrm{mg} / \mathrm{ml}(5.0 \mu \mathrm{M})$, and the C3b-FH complex was formed by incubating the mixture at $4{ }^{\circ} \mathrm{C} 2 \mathrm{~h}$ before adding zinc, all in HEPES buffer with $0.5 \mathrm{~mm}$ Pefabloc-SC ${ }^{70}$. $\mathrm{ZnSO}_{4}$ was added at concentrations of $2,6,20,60,120,200$, and $600 \mu \mathrm{M}$ up to $2 \mathrm{~h}$ before the measurements. Other details including data reduction are described elsewhere $(46,48)$.

In a given solute-solvent contrast, the radius of gyration $R_{G}$ corresponds to the mean square distance of scattering elements from their center of gravity and is a measure of structural elongation. Guinier analyses at low $Q$ values gives the $R_{G}$ value and the forward scattering at zero angle $I(0)$ from the expression (49),

$$
\ln I(Q)=\ln I(0)-R_{G}^{2} Q^{2} / 3
$$

This expression is valid in a $Q . R_{G}$ range up to 1.5 . The $I(0) / c$ value (c is the protein concentration in $\mathrm{mg} / \mathrm{ml}$ ) is proportional to the relative molecular mass $M_{\mathrm{r}}$. The Guinier analyses were performed using an interactive PERL script program SCTPL7 (J. T. Eaton and S. J. Perkins, unpublished software) on Silicon Graphics OCTANE Workstations.

Indirect transformation of the $I(Q)$ curve measured in reciprocal space into real space gives the distance distribution function $P(r)$ and was carried out using the program GNOM (50),

$$
P(r)=\frac{1}{2 \pi^{2}} \int I(Q) Q r \sin (Q r) d Q
$$

$P(r)$ corresponds to the distribution of distances $r$ between volume elements and gives an alternative calculation of the $R_{G}$ and $I(0)$ values based on the full scattering curve $I(Q)$. It also gives the most frequently occurring distance $M$ within the macromolecule and the maximum dimension of the macromolecule $L$. For C3, C3u, C3b, C3c, and C3d titrated with zinc, the $\mathrm{x}$-ray curves utilized up to 320 data points in the $Q$ range between 0.09 and 1.50 $\mathrm{nm}^{-1}$. Other details are described elsewhere $(31,46,48)$.

Prediction of Zinc Binding Sites-Potential zinc binding sites were predicted utilizing the METSITE server (37). METSITE predicts binding sites for different metals utilizing a broad set of structural identifiers. For a given metal, the characterization of the secondary structure, solvent accessibility, position-specific scoring matrix, and distance matrix ascertains those residues most likely to interact strongly with metal. METSITE utilizes the distances between the $C \beta$ atoms of amino acid residues except for Gly residues when $\mathrm{C} \alpha$ atoms were used. For this pro- ject, the capacity of METSITE was expanded by Dr. Daniel Buchan and Prof. David T. Jones to process larger protein structures. The predictions used crystal structures for $\mathrm{C} 3$ (PDB code 2A73) (4), C3b (PDB codes 2I07 and 2ICF) (51, 52), C3c (PDB code 2A74) (4), and C3d (PDB codes 1C3D and 1GHQ $(53,54)$, and a solution structure for C3u (PDB code 3MMQ) (43). In METSITE, the false positive rate was set to $5 \%$, and the predicted metal was set to zinc. For structures with multiple chains, all chains were relabeled to be chain A to circumvent a METSITE limitation of only being able to process single chain structures. His, Glu, Asp, and Cys residues with neural network scores greater than 0.7 were accepted as potential zinc binding residues, whereas Arg and Gly residues were removed because they do not bind zinc (35). The METSITE output was summarized in tabular form in which a neural network residue score of 0.7 represents a $\log$ likelihood ratio of $\sim 1$. At a log likelihood ratio of 2 , there are 100 correct predictions for every false positive, indicating a high level of confidence (37).

\section{RESULTS}

Sedimentation Velocity of C3, C3u, C3b, C3c, and C3d with Zinc-C3, C3u, C3b, and C3c were studied at concentrations of $4.0-4.6 \mu \mathrm{M}$, which are comparable with the physiological C3 concentration of about $1.0 \mathrm{mg} / \mathrm{ml}(5.3 \mu \mathrm{M})$ in plasma (2). C3d was studied at $0.27 \mathrm{mg} / \mathrm{ml}(7.8 \mu \mathrm{M})$, this being the lowest concentration that produced analyzable data. HEPES buffer was used to avoid the precipitation of zinc that occurs if phosphate buffer is used. Each protein was titrated using a concentration range of $0.2-600 \mu \mathrm{M} \mathrm{ZnSO}_{4}$.

Analytical ultracentrifugation studies the sedimentation behavior of macromolecules when they are subjected to a high centrifugal force to determine their sizes and shapes (55). This method is advantageous for the detection of multiple species that are present. In sedimentation velocity experiments with C3, C3u, C3b, C3c, and C3d, each was titrated with zinc. Good fits to the sedimentation boundaries in all cases (Fig. 1F) resulted in well defined size distribution analyses $c(s)$. The five proteins each showed different sedimentation behavior as the zinc concentrations increased.

For C3 titrated with zinc, the monomer peak was consistently observed at an $s_{20, w}$ value of $8.42 \pm 0.10 \mathrm{~S}$ with a molecular mass of $182 \pm 4 \mathrm{kDa}$ at all zinc concentrations (Fig. 1A). Both values agree well with those of $\mathrm{C} 3$ without zinc at $8.49 \pm$ $0.03 \mathrm{~S}$ and $192 \pm 8 \mathrm{kDa}$ and with the sequence-determined molecular mass of $189.0 \mathrm{kDa}(43) .{ }^{4}$ The intensity of the C3 monomer peak decreased as the zinc concentrations increased. This indicated the presence of unperturbed C3 monomer even with a 40 -fold excess of zinc, meaning the binding of zinc is weak. Starting from a zinc concentration of $60 \mu \mathrm{M}$, the monomer peak broadened, and a second broad peak appeared that corresponded to soluble $\mathrm{C} 3$ oligomers with higher $s_{20, w}$ values of $10.2 \mathrm{~S}$ at $60 \mu \mathrm{M}$ zinc, $12.3 \mathrm{~S}$ at $120 \mu \mathrm{M}$ zinc, and $13.7 \mathrm{~S}$ at 200 $\mu \mathrm{M}$ zinc (Fig. 1A). The apparent molecular masses of these peaks were 244,321 , and $378 \mathrm{kDa}$, respectively, suggesting that

\footnotetext{
${ }^{4}$ Our previous study (43) reported $s$ values of $7.85 \pm 0.05 \mathrm{~S}$ for $\mathrm{C} 3$ and $7.44 \pm$ $0.07 \mathrm{~S}$ for $\mathrm{C} 3 \mathrm{u}$, when these should have been presented as $s_{20, w}$ values of $8.49 \pm 0.03 \mathrm{~S}$ and $8.08 \pm 0.02 \mathrm{~S}$ respectively.
} 


\section{Zinc-induced Oligomerization of C3}
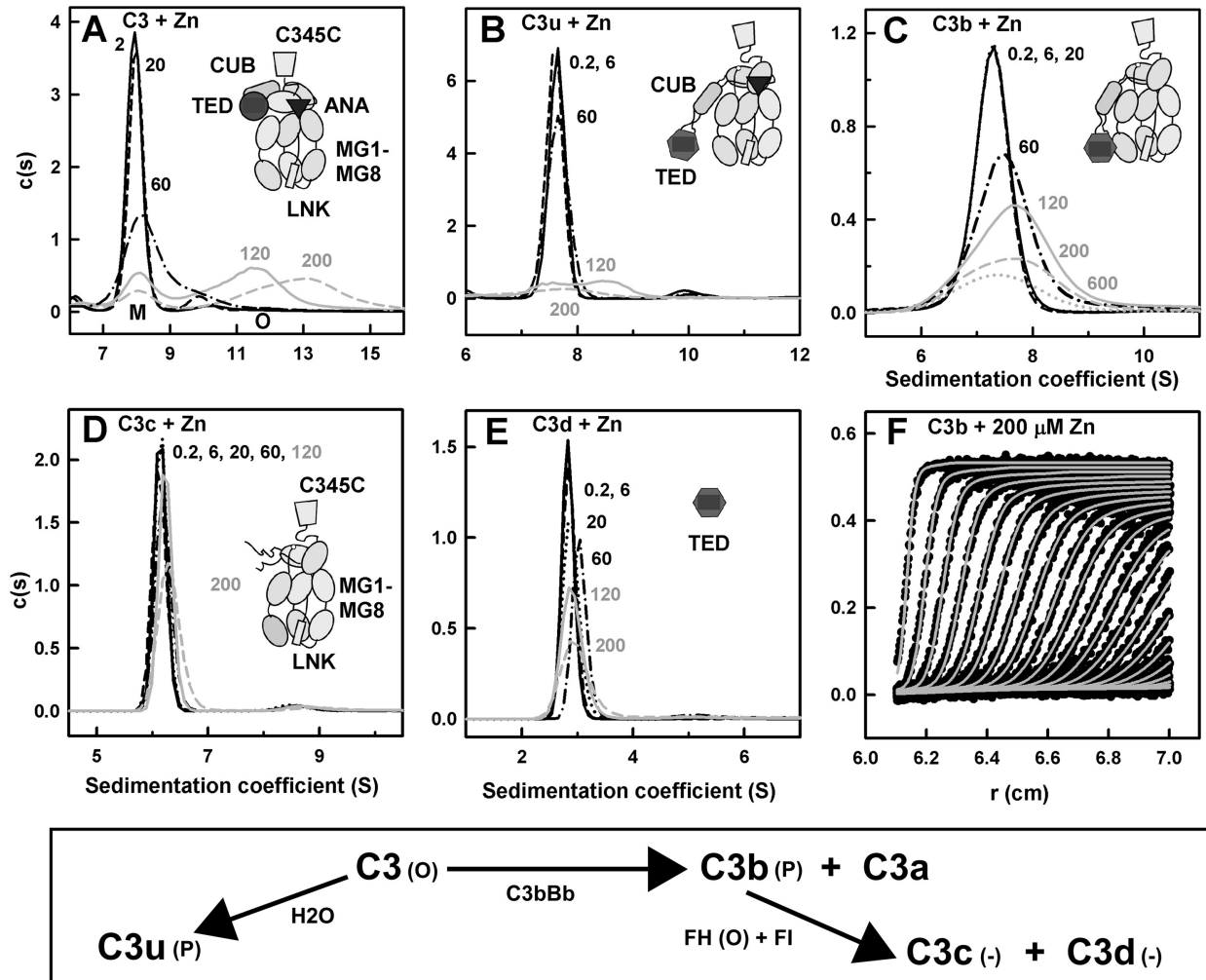

FIGURE 1. Sedimentation velocity analyses of $\mathbf{C 3}, \mathbf{C 3 u}, \mathbf{C 3 b}, \mathbf{C 3 c}$, and $\mathbf{C 3 d}$ in the presence of zinc. C3, C3u, C3b, and C3c were studied at $4.4 \mu \mathrm{M}$, and C3d was studied at $7.8 \mu \mathrm{m}$. The 10-13 domains of $\mathrm{C} 3, \mathrm{C} 3 \mathrm{u}, \mathrm{C} 3 \mathrm{~b}$, and $\mathrm{C} 3 \mathrm{c}$ are depicted as schematics with the TED (circle or hexagon) and ANA (triangle) domains shown in dark outlines when present. Beneath the $c(s)$ plots, a schematic summary of the relationships between the five forms of $C 3$ is shown. Oligomers, precipitates, or no changes upon adding zinc are denoted by $P, O$, and -, respectively. $A$, the $c(s)$ sedimentation coefficient distribution analysis for $C 3$ with zinc concentrations at $2 \mu \mathrm{m}$ (solid black line), $20 \mu \mathrm{M}$ (black dashes), $60 \mu \mathrm{m}$ (black dots and dashes), $120 \mu \mathrm{m}$ (solid gray line), and $200 \mu \mathrm{m}$ (gray dashes). The monomer peak is denoted as $M$, and the oligomer peaks at high $S$ values are denoted as $O$. Here and below, the zinc concentrations in $\mu M$ are denoted numerically. $B$, the $c(s)$ analysis for C $3 \mathrm{u}$ with zinc concentrations at $0.2 \mu \mathrm{m}$ (line) and $6 \mu \mathrm{m}$ (dashes) and three higher zinc concentrations are shown as in $A$. C, the $c(s)$ analysis for C $3 \mathrm{~b}$, with zinc concentrations at $0.2 \mu \mathrm{M}$ (line), $6 \mu \mathrm{M}$ (dashes), and $20 \mu \mathrm{M}$ (dots), and three higher zinc concentrations are shown as in $A$. D, the $c(s)$ analysis for C3c with zinc concentrations are shown as in $C$. $E$, the $c(s)$ analysis for $C 3 \mathrm{~d}$ with zinc concentrations are shown as in $C$. F, shown are the sedimentation boundary fits for C3b with $200 \mu \mathrm{M}$ zinc; all 30 scans are shown. The experimental absorbance data are shown as black circles, whereas the boundary fits are shown as gray lines.

progressive $\mathrm{C} 3$ oligomer formation as dimer or trimer or higher has occurred in the presence of excess zinc.

For $\mathrm{C} 3 \mathrm{u}$ titrated with zinc, the monomer peak was consistently observed at an $s_{20, w}$ value of $8.05 \pm 0.11 \mathrm{~S}$ with a molecular mass value of $176 \pm 3 \mathrm{kDa}$ at all zinc concentrations. These values agreed with those of $\mathrm{C} 3 \mathrm{u}$ without zinc at $8.08 \pm 0.03 \mathrm{~S}$ and $172 \pm 16 \mathrm{kDa}(43)$. Unlike $\mathrm{C} 3$, the $\mathrm{C} 3 \mathrm{u}$ monomer peak almost disappeared as the zinc concentration increased to 120 and $200 \mu \mathrm{M}$, and no significant oligomer peaks were observed at high zinc concentrations (Fig. 1B). This showed that C3u precipitated in the presence of excess zinc.

For C3b, the monomer peak was observed at a $s_{20, w}$ value of $7.41 \pm 0.01 \mathrm{~S}$ and a molecular mass value of $160 \pm 0.3 \mathrm{kDa}$ for zinc concentration to $20 \mu \mathrm{M}$ (Fig. 1C). At zinc concentrations of $60 \mu \mathrm{M}$ and above, the monomer $s_{20, w}$ value increased slightly, from $7.62 \mathrm{~S}$ at $60 \mu \mathrm{M}$ zinc to $7.76 \mathrm{~S}$ at $200 \mu \mathrm{M}$ zinc. The peak shift is attributed to the onset of $\mathrm{C} 3 \mathrm{~b}$ oligomer formation in the presence of zinc, this being less pronounced than that observed for C3. At the same time, the C3b peak intensity also decreased as the zinc concentrations increased, indicating precipitation. No separate oligomer peak was observed for C3b-zinc (Fig. 1C). Thus $\mathrm{C} 3 \mathrm{~b}$ behaved differently from $\mathrm{C} 3$ or $\mathrm{C} 3 \mathrm{u}$ in the presence of zinc.

For C3c, the monomer peak was observed at a $s_{20, w}$ value of $6.51 \pm 0.07 \mathrm{~S}$ with a molecular mass value of $121 \pm 2 \mathrm{kDa}$ at all zinc concentrations. This agrees with that for C3c in the absence of zinc. No change in $s_{20, w}$ value or intensity was observed until zinc concentrations reached $200 \mu \mathrm{M}$ when the monomer peak became broader, this being attributed to the onset of C3c oligomer formation (Fig. 1D).

For C3d, the monomer was consistently observed at a $s_{20, w}$ value of $3.13 \pm 0.09 \mathrm{~S}$ with a molecular mass of $34 \pm 1 \mathrm{kDa}$, and no significant oligomer peak was visible. These data agree well with the $s_{20, w}$ value of $3.0 \pm 0.1 \mathrm{~S}$ and a molecular mass value of $34 \pm 4 \mathrm{kDa}$ for monomeric C3d in $137 \mathrm{~mm} \mathrm{NaCl}$ (56). Starting at a zinc concentration of $60 \mu \mathrm{M}$, the $\mathrm{C} 3 \mathrm{~d}$ monomer peak decreased in intensity as the zinc concentration increased but less so than C3, C3u, and C3b (Fig. $1 E$ ).

The integration of the monomer peak intensities in the $c(s)$ analyses permitted comparison of the effect of zinc on the solubility of the five proteins. For reason of clarity, the integrations were normalized to $100 \%$ at $0-2 \mu \mathrm{m}$ zinc. C3, C3u, and C3b decreased significantly at zinc concentrations of $120 \mu \mathrm{M}$ and above with similar apparent protein-zinc dissociation constants $K_{D}$ of around $100 \mu \mathrm{M}$ (Fig. 2A). C3 and C3u decreased more strongly in intensity than $\mathrm{C} 3 \mathrm{~b}$ at zinc concentrations of $120 \mu \mathrm{M}$ and above. Of those three proteins, only C3 formed soluble oligomers that increased to $\sim 80 \%$ of the $\mathrm{C} 3$ present. This increase in C3 oligomer matched the decrease of the C3 
monomer for zinc concentrations of $120 \mu \mathrm{M}$ and above. Unlike $\mathrm{C} 3, \mathrm{C} 3 \mathrm{u}$, and $\mathrm{C} 3 \mathrm{~b}$, the $\mathrm{C} 3 \mathrm{c}$ monomer was not affected in intensity by the increase in zinc concentrations up to $200 \mu \mathrm{M}$, whereas the amount of the C3d monomer was slightly reduced at zinc concentrations above $60 \mu \mathrm{M}$, and $64 \%$ of C3d remained as a soluble monomer in $200 \mu \mathrm{M}$ zinc (Fig. 2B). Neither C3c nor C3d precipitated or formed large oligomers in the manner seen for $\mathrm{C} 3, \mathrm{C} 3 \mathrm{u}$, and $\mathrm{C} 3 \mathrm{~b}$. It was concluded that the presence of both the $\mathrm{C} 3 \mathrm{~d}$ and $\mathrm{C} 3 \mathrm{c}$ regions within $\mathrm{C} 3, \mathrm{C} 3 \mathrm{u}$, and $\mathrm{C} 3 \mathrm{~b}$ is required for these to self-associate with zinc even though either C3d or C3c on their own do not self-associate with zinc.

To assess whether other plasma proteins undergo self-association in the presence of zinc, $0.32 \mathrm{mg} / \mathrm{ml}(4 \mu \mathrm{M})$ human serum
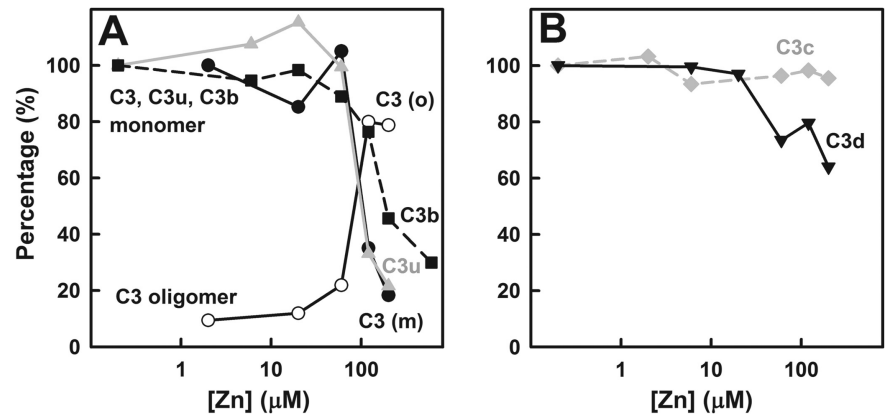

FIGURE 2. The percentages of the monomers and oligomers of the five $\mathrm{C3}$ proteins as a function of zinc concentrations. These were determined from the $c(s)$ analyses of Fig. 1. A, C3 (filled circle, monomer; open circle, oligomer, black line); $\mathrm{C} 3 \mathrm{u}$ (gray triangle, monomer; gray line); $\mathrm{C} 3 \mathrm{~b}$ (filled square, monomer, black dashes). B, C3c (gray diamond, monomer; gray dashes); C3d (black inverted triangle, monomer, black line).
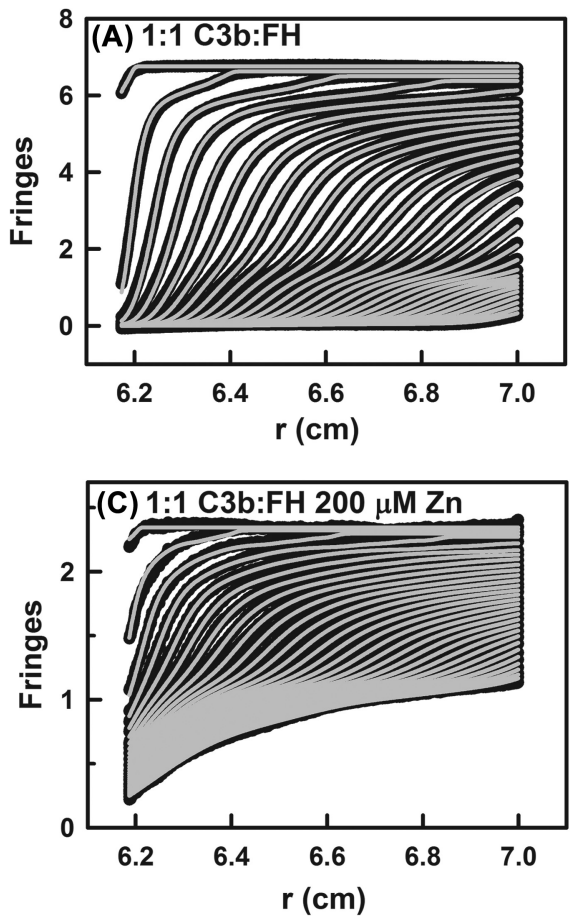

albumin in HEPES buffer was titrated with seven concentrations of $\mathrm{ZnSO}_{4}$ between 0.2 and $600 \mu \mathrm{M}$. The $c(s)$ analyses revealed one major peak at a $s_{20, w}$ value of $4.95 \pm 0.06 \mathrm{~S}$ and a molecular mass value of $67 \pm 1 \mathrm{kDa}$ that was unaltered in $0.2-$ $600 \mu \mathrm{M}$ zinc (data not shown). This indicated that human serum albumin does not self-associate in the presence of zinc.

Sedimentation Velocity of the C3b-FH Complex with ZincSedimentation velocity experiments were performed on a 1:1 mixture of $\mathrm{FH}$ at $0.85 \mathrm{mg} / \mathrm{ml}(5.5 \mu \mathrm{M})$ and $\mathrm{C} 3 \mathrm{~b}$ at $0.99 \mathrm{mg} / \mathrm{ml}$ $(5.5 \mu \mathrm{M})$ (Fig. $3 A$ ). The $K_{D}$ value is $0.6-1.6 \mu \mathrm{M}$ for the FH-C3b complex (9). Accordingly, 60-70\% FH-C3b complex formation is expected. Unbound monomeric $\mathrm{FH}$ was observed at a $s_{20, w}$ value of $5.58 \mathrm{~S}$, and this corresponded to a molecular mass value of $143 \mathrm{kDa}$, which is close to the sequence-predicted mass of $154 \mathrm{kDa}$ (Fig. $3 B$ ). The peak with a $s_{20, w}$ value of $9.18 \mathrm{~S}$ and a molecular mass value of $287 \mathrm{kDa}$ was attributed to the $1: 1 \mathrm{com}$ plex of $\mathrm{FH}-\mathrm{C} 3 \mathrm{~b}$ with a sequence-predicted molecular mass value of $334 \mathrm{kDa}$. Unbound monomeric C3b was an unresolved shoulder at a $s_{20, w}$ value of $\sim 7.5 \mathrm{~S}$ that overlapped with the major peak at $9.18 \mathrm{~S}$. Small amounts of other species were observed at $s_{20, w}$ values higher than $10 \mathrm{~S}$; however, their peaks were not well resolved and were not considered further here.

The effect of zinc on the 1:1 complex of C3b and $\mathrm{FH}$ was now investigated. Given that the $K_{D}$ for the FH-zinc interaction is $\sim 10 \mu \mathrm{M}(31,32)$ and that for C3b-zinc is $\sim 100 \mu \mathrm{M}$ (Fig. $2 A$ ), both zinc interactions are weaker than that for the FH-C3b complex. Good fits to the sedimentation boundaries with 60, 120 , and $200 \mu \mathrm{M}$ of zinc were obtained in all cases (Fig. 3C). On
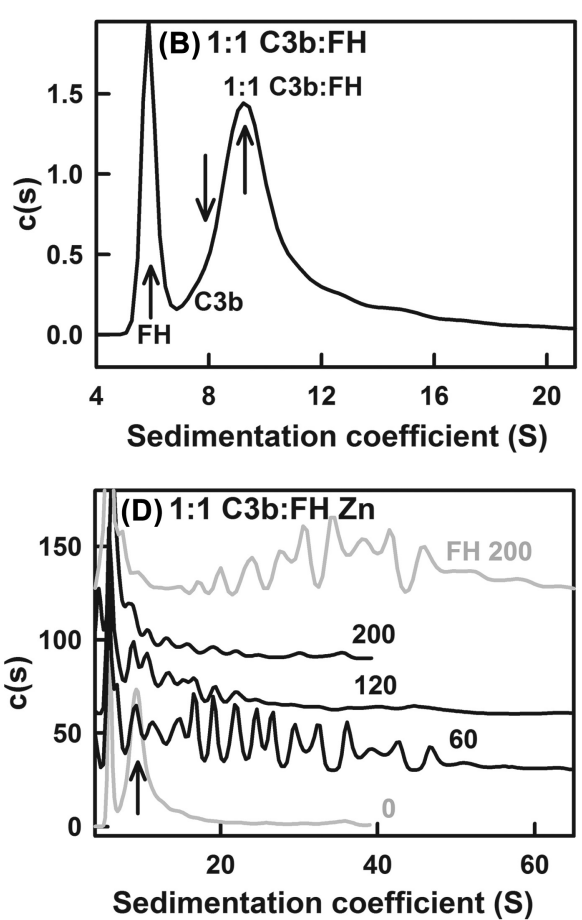

FIGURE 3. Sedimentation velocity analyses of the C3b-FH complex in the presence of zinc. $A$, shown are the boundary fits for the 1:1 mixture of $5.5 \mu \mathrm{m} C 3 \mathrm{~b}$ and $5.5 \mu \mathrm{M} \mathrm{FH}$. Only every tenth scan of the 300 scans is shown for clarity. The absorbance data are shown as black circles, whereas boundary fits are shown as gray lines. $B$, shown is the $c(s)$ sedimentation coefficient distribution analysis for the 1:1 mixture of C $3 \mathrm{~b}$ and $\mathrm{FH}$. The peak positions for the $\mathrm{FH}$ monomer (5.77 S), C3b monomer (8.16 S), and the 1:1 C3b-FH complex (9.55 S) are arrowed. C, the boundary fits for the 1:1 mixture of 5.5 $\mu \mathrm{M} \mathrm{FH-C3b}$ and 5.5 $\mu \mathrm{m} \mathrm{FH} \mathrm{with} 200 \mu \mathrm{M}$ zinc following the representation of $A$. $D$, the $c(s)$ analyses for the 1:1 mixture of $\mathrm{FH}: \mathrm{C} 3 \mathrm{~b}$ with $60 \mu \mathrm{M}, 120 \mu \mathrm{M}$, and $200 \mu \mathrm{M}$ zinc (black outlines) are shown. The analyses are normalized relative to the $\mathrm{FH}$ monomer peak. The zinc concentrations are denoted numerically. The peak position of the 1:1 FH-C3b complex is shown with an arrow. For comparison, the two $c(s)$ curves (gray outlines) for the complex from $B$ with no zinc present and for $\mathrm{FH}$ alone with $200 \mu \mathrm{M}$ zinc from Fig. $4 D$ of (31) are shown to the same scale. 

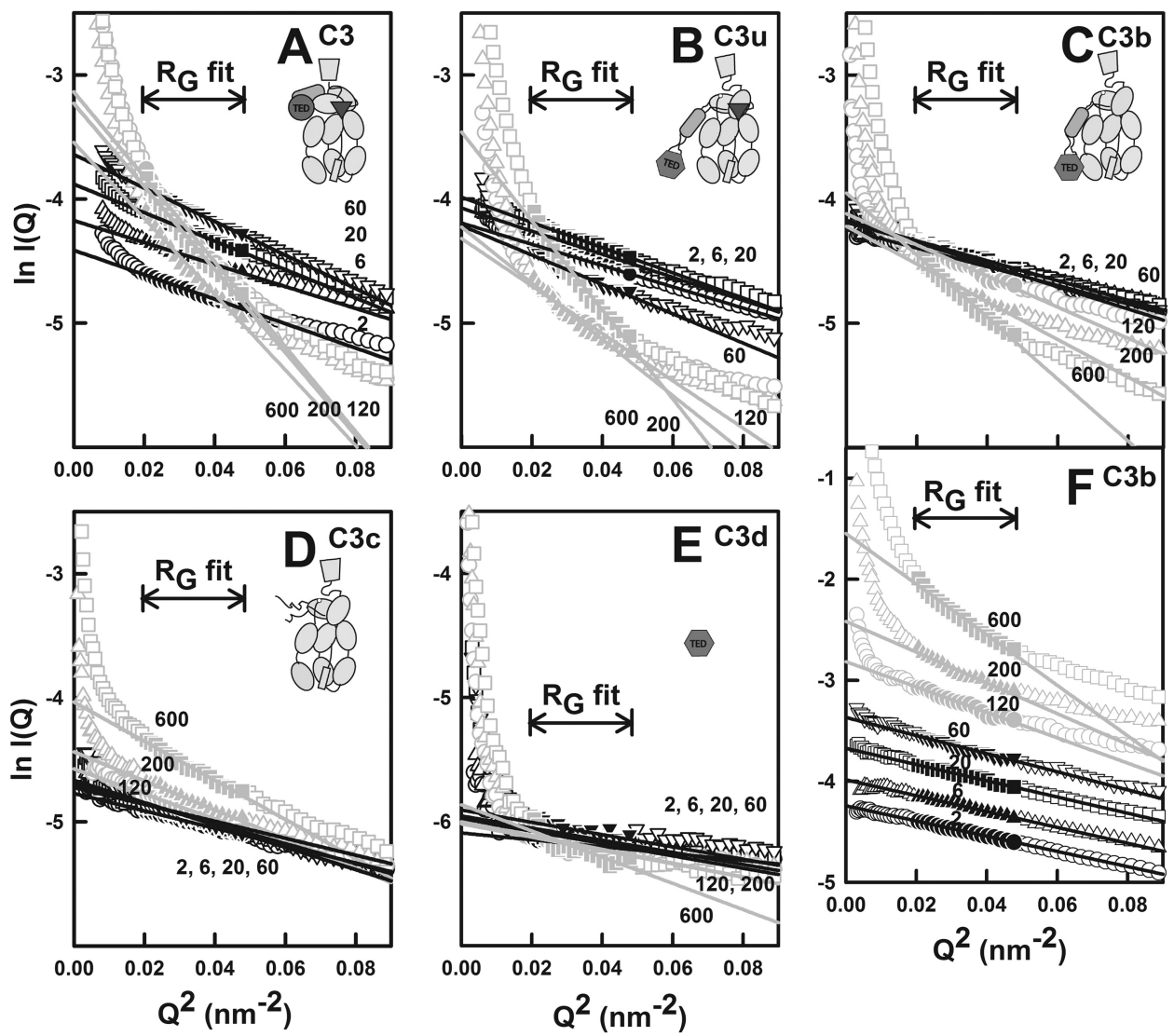

FIGURE 4. X-ray Guinier analyses of In I(Q) versus $Q^{2}$ for C3, C3u, C3b, C3c, and C3d titrated with zinc. For clarity, the 10-13 domains of C3, C3u, C3b, and $\mathrm{C} 3 \mathrm{C}$ are depicted as schematics. In all panels, the open symbols correspond to the experimental data, and the filled symbols correspond to those used for the Guinier straight line fits. The $Q$ fit range was $0.14-0.22 \mathrm{~nm}^{-1}$ in all cases (arrow ranges), and the zinc concentrations in micromolar are numerically labeled as shown. The Guinier $R_{G}$ plots are shown for $C 3(A), C 3 \mathrm{u}(B), \mathrm{C} 3 \mathrm{~b}(\mathrm{C}$ and $F)$, and $C 3 \mathrm{C}(D)$, all at $\sim 4 \mu \mathrm{M}$, and for $\mathrm{C} 3 \mathrm{~d}(E)$ at $14.5 \mu \mathrm{M}$. The $\mathrm{ZnSO}{ }_{4}$ concentrations were 2 $\mu \mathrm{M}(\bigcirc), 6 \mu \mathrm{M}(\triangle), 20 \mu \mathrm{M}(\square)$, and $60 \mu \mathrm{M}(\nabla)$, all shown in black, and $120 \mu \mathrm{M}(\bigcirc), 200 \mu \mathrm{M}(\triangle)$, and $600 \mu \mathrm{M}(\square)$, all shown in gray. In $F$, the $C 3 \mathrm{~b}$ Guinier plots from $C$ are displaced in steps of $0.2 \mathrm{log}$ units to show the processes of aggregation and precipitation more clearly.

adding zinc, the peak for monomeric $\mathrm{FH}$ at $5.58 \mathrm{~S}$ was consistently observed at all zinc concentrations (Fig. 3D). The peak intensity of monomeric FH decreased from $100 \%$ with no zinc to $43 \%$ at $200 \mu \mathrm{M}$ zinc. At $60 \mu \mathrm{M}$ zinc, multiple peaks with $s_{20, w}$ values up to $50 \mathrm{~S}$ were observed. The intensity of these oligomer peaks were much higher than for only $\mathrm{FH}$ with $60 \mu \mathrm{M}$ zinc, and both the FH monomer and C3b-FH peaks decreased in intensity, indicating that these peaks correspond to a mixture of FH-Zn and C3b-FH-Zn oligomers (see Fig. 1 of Ref. 32). At 120 and $200 \mu \mathrm{M}$ zinc, these multiple peaks showed clear decreases in intensity, showing that the $\mathrm{C} 3 \mathrm{~b}-\mathrm{FH}$-zinc oligomers precipitated when zinc was above $100 \mu \mathrm{M}$. The corresponding experiment with $\mathrm{FH}$ in $200 \mu \mathrm{m}$ zinc showed that FH-zinc oligomers were much more soluble in the absence of $\mathrm{C} 3 \mathrm{~b}$ (32). In addition, the major peak for the C3b-FH complex at $9.18 \mathrm{~S}$ was reduced in 60 and $120 \mu \mathrm{m}$ zinc and disappeared in $200 \mu \mathrm{M}$ zinc. These decreased peak intensities with $120-200 \mu \mathrm{M}$ zinc is attributed to the formation of very large C3b-FH-zinc complexes that precipitate and sediment rapidly to the bottom of the ultracentrifuge cell even before the first scan was recorded.

$X$-ray Scattering of C3, C3u, C3b, C3c, and C3d with ZincSmall-angle $\mathrm{X}$-ray scattering is a diffraction method for the study of solution structures of macromolecules in random orientations (57). The effect of zinc on freshly purified C3, C3u, $\mathrm{C} 3 \mathrm{~b}, \mathrm{C} 3 \mathrm{c}$, and C3d were investigated by $\mathrm{x}$-ray scattering. C3,
$\mathrm{C} 3 \mathrm{u}, \mathrm{C} 3 \mathrm{~b}$, and $\mathrm{C} 3 \mathrm{c}$ were again studied at $4 \mu \mathrm{m}$, whereas C3d was studied at $14.5 \mu \mathrm{M}(0.50 \mathrm{mg} / \mathrm{ml})$, this being the lowest concentration of C3d that produced analyzable $x$-ray data. Each protein was titrated with 2-600 $\mu \mathrm{M} \mathrm{ZnSO}_{4}$. The scattering data $I(Q)$ showed excellent signal-noise ratios and no detectable effect from radiation damage.

The Guinier fits at low $Q$ values (where $Q=4 \pi \sin \theta / \lambda ; 2 \theta=$ scattering angle; $\lambda=$ wavelength) detect aggregates more readily than ultracentrifugation (31). The Guinier radius of gyration $\left(R_{G}\right)$ monitors the degree of elongation of the protein, and Guinier $I(0) / c$ value is proportional to the relative molecular mass $(49,57)$. The fits for the five proteins were performed in a restricted $Q$ range from 0.14 to $0.22 \mathrm{~nm}^{-1}$, even though good Guinier linearity continued to $0.45 \mathrm{~nm}^{-1}$ at low zinc concentrations, because this reduced $Q$ range provided a sensitive monitor for aggregation.

For C3 at the lowest zinc concentration of $2 \mu \mathrm{M}$ and for 6, 20, and $60 \mu \mathrm{M}$ zinc, the mean $R_{G}$ value was $5.43 \pm 0.02 \mathrm{~nm}$, which is higher than that of $4.52 \pm 0.08 \mathrm{~nm}$ for native $\mathrm{C} 3$ without zinc in the larger $Q$ range from 0.13 to $0.30 \mathrm{~nm}^{-1}$ (43). This increase is attributed to minor aggregation of $\mathrm{C} 3$, the latter being visible as a slight upturn in the scattering curve at the lowest $Q$ values (Fig. $4 A$ ). For 120, 200, and $600 \mu \mathrm{M}$ zinc, the $I(Q)$ intensities increased significantly at low $Q$ values as the result of zincinduced aggregation. At larger $Q$ values, these $I(Q)$ intensities 

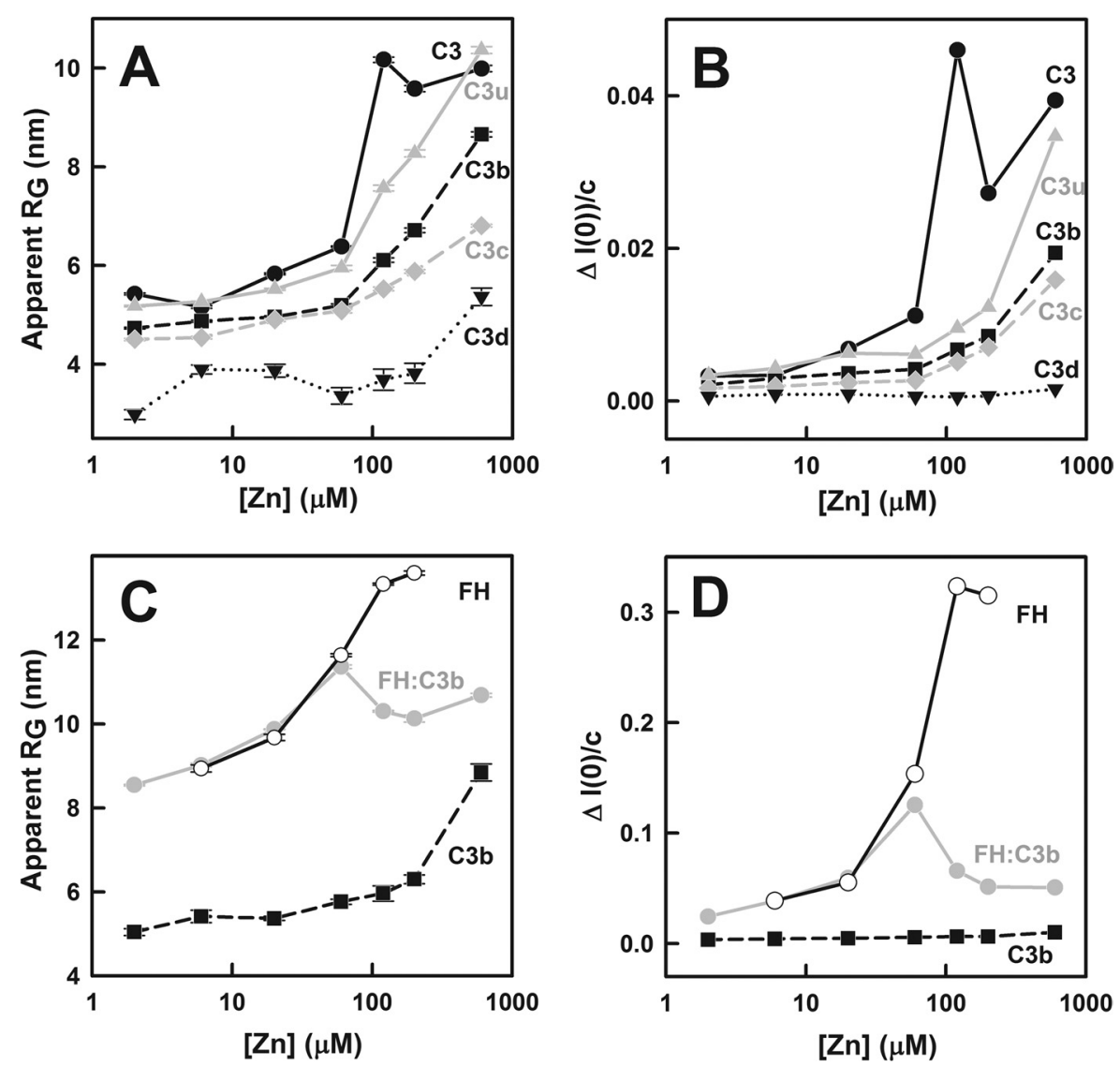

FIGURE 5. Dependence of the Guinier $\boldsymbol{R}_{G}$ and $I(\mathbf{0}) / c$ parameters on zinc concentrations from $\mathbf{2}$ to $\mathbf{6 0 0} \boldsymbol{\mu m}$. Each value was measured in quadruplicate and averaged, and statistical error bars are shown where visible. $A$, the apparent $R_{G}$ values for C3 (black circles, black line), C3u (gray triangles, gray line), C3b (black squares, black dashes), C3c (gray diamonds, gray dashes) and C3d (inverted black triangles, dotted line) were determined from the fits of Fig. 4, A-E. B, shown is the change in the I(0)/c values between the Guinier plots, the difference based on the $Q$ fit ranges of $0.14-0.22$ and $0.32-0.45 \mathrm{~nm}^{-1}$ for C3, C3u, C3b, C3c, and C3d using the same symbols as in $A$. C, the apparent $R_{G}$ values for $\mathrm{FH}$ (open circles, black line), the FH-C3b complex (gray circles, gray line), and C3b (black squares, dashed line) measured in another beam session are compared with each other (the Guinier fits are not shown). $D$, shown is the change in the $I(0) / c$ values between the Guinier plots, the difference based on the $Q$ fit ranges of $0.14-0.22$ and $0.32-0.45 \mathrm{~nm}^{-1}$ for FH, the C3b-FH complex, and C3b, using the same symbols as in $C$.

dropped for reasons of protein losses (precipitation). These $I(Q)$ changes led to significant increases in the apparent $R_{G}$ value, which represents the average $R_{G}$ values of the monomeric and aggregated species (Fig. $5 A$ ) (58).

For $\mathrm{C} 3 \mathrm{u}$ at a zinc concentration of $2 \mu \mathrm{M}$, the mean $R_{G}$ value was $5.18 \pm 0.16 \mathrm{~nm}$, which is close to the value of $4.88 \pm 0.23$ $\mathrm{nm}$ in the $Q$ range from 0.13 to $0.30 \mathrm{~nm}^{-1}$ for C3u without zinc (43). Some minor aggregation was visible at the lowest $Q$ values (Fig. 4B). As for C3, little changes occurred at 6-60 $\mu \mathrm{M}$ zinc, whereas significant increases in intensity and the apparent $R_{G}$ value were seen at $120-600 \mu \mathrm{M}$ zinc (Fig. $5 A$ ). In this case, the larger decrease in intensities at the larger $Q$ values showed that more protein precipitation of C3u occurred at 120-600 $\mu \mathrm{M}$ zinc.

For C3b with $2 \mu \mathrm{M}$ zinc, the mean $R_{G}$ value was $4.73 \pm 0.16$ $\mathrm{nm}$, which is close to that of $4.88 \pm 0.23 \mathrm{~nm}$ above for C3u without zinc (43). As for $\mathrm{C} 3$ and $\mathrm{C} 3 \mathrm{u}$, little changes occurred for zinc concentrations at 6-60 $\mu \mathrm{M}$. Significant increases in intensity and apparent $R_{G}$ value were seen for zinc concentrations at $120-600 \mu \mathrm{M}$ together with protein precipitation seen at larger $Q$ (Figs. $4 C$ and $5 A$ ). The increased aggregation with increase in zinc concentration is more clearly seen in the curves that were replotted with offsets (Fig. 4F).
For C3c with $2 \mu \mathrm{M}$ zinc, the mean $R_{G}$ value was $4.50 \pm 0.13$ $\mathrm{nm}$ with $2 \mu \mathrm{m}$ zinc; this $R_{G}$ value is similar to those for $\mathrm{C} 3 \mathrm{u}$ and $\mathrm{C} 3 \mathrm{~b}$ above. Unlike C3, C3u, and C3b, the scattering curves showed little change for zinc concentration up to $60 \mu \mathrm{M}$ and only modest increases in intensities for zinc from 120 to $600 \mu \mathrm{M}$ (Fig. $4 D$ ). The apparent $R_{G}$ increases were much smaller than those seen for C3, C3u, and C3b (Fig. 5A).

For C3d with $2 \mu \mathrm{M}$ zinc, the apparent $R_{G}$ value of C3d was $2.98 \pm 0.30 \mathrm{~nm}$ in the $Q$ range of 0.14 to $0.22 \mathrm{~nm}^{-1}$ (Fig. $4 E$ ). C3d is small, and a larger Guinier $Q$ fit range is normally used. The $R_{G}$ value was $1.95 \mathrm{~nm}$ in the $Q$ fit range of $0.16-0.55 \mathrm{~nm}^{-1}$, in good accord with the $R_{G}$ value of $2.02 \mathrm{~nm}$ calculated from its crystal structure (59). Here, the Guinier fits with a $Q$ range of $0.14-0.22 \mathrm{~nm}^{-1}$ were almost unchanged between 2 and $600 \mu \mathrm{M}$ zinc. At the lowest $Q$ values below $0.14 \mathrm{~nm}^{-1}$, intensity increases were seen for 200 and $600 \mu \mathrm{M}$ zinc, showing that slight aggregates have formed together with some minor precipitation seen at large $Q$ (Fig. $4 E$ ). The apparent $R_{G}$ increases were the smallest compared with the other four proteins (Fig. $5 A$ ). It was concluded that $\mathrm{C} 3 \mathrm{~d}$ remained mostly monomeric in solution for zinc concentrations between 2 and $600 \mu \mathrm{M}$.

When aggregates are present, the observed scattering curve is the sum of the scattering curves of the macromolecular spe- 


\section{Zinc-induced Oligomerization of C3}
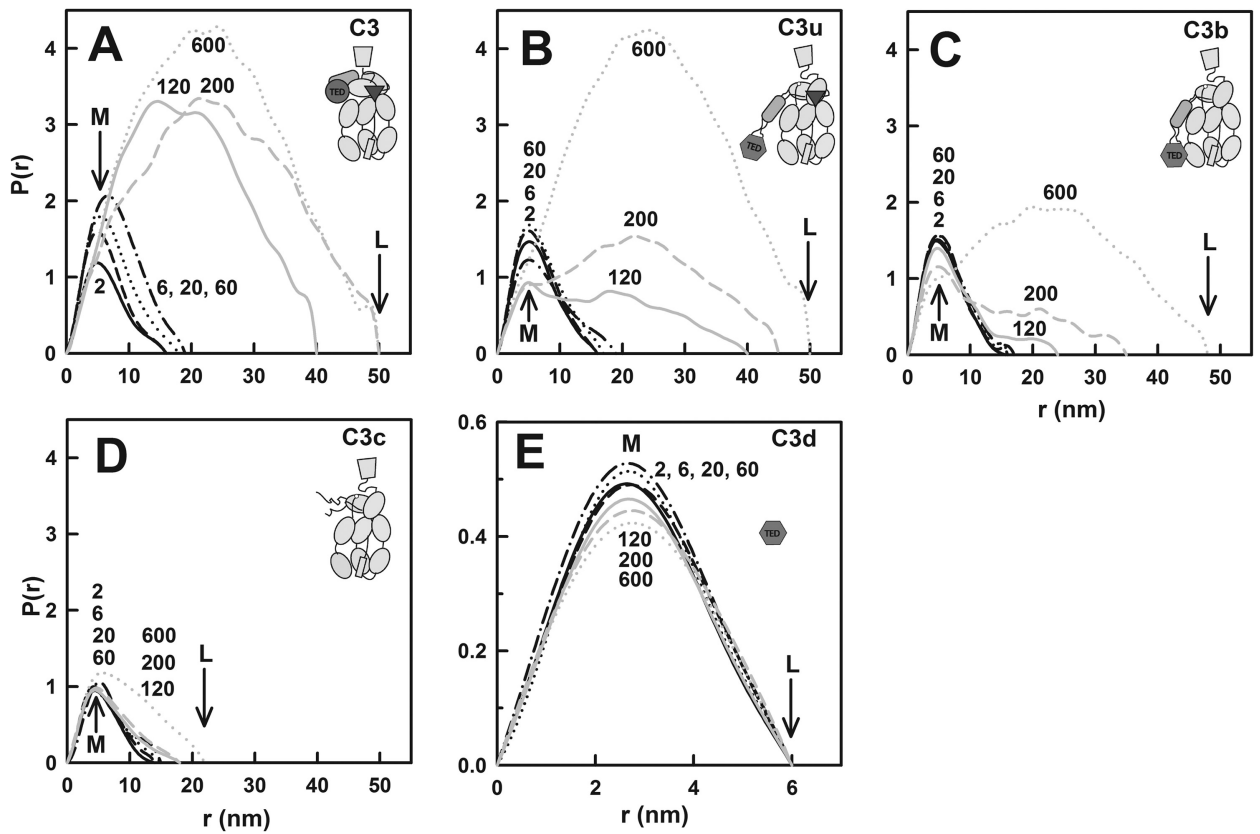

FIGURE 6. Dependence of the distance distribution function $P(r)$ of $C 3, C 3 u, C 3 b, C 3 c$, and $C 3 d$ on zinc concentrations from 2 to $600 \mu \mathrm{M}$. For clarity, the 10-13 domains of C3, C3u, C3b, and C3c are depicted as schematics. The $P(r)$ curves were calculated from the I( $Q)$ curves used in Fig. 4. A, C3; $B, C 3 \mathrm{u} ; C, C 3 \mathrm{~b} ; D$, C3c; E, C3d. The zinc concentrations were $2 \mu \mathrm{m}$ (black line), $6 \mu \mathrm{m}$ (black dashed line), $20 \mu \mathrm{m}$ (black dotted line), $60 \mu \mathrm{M}$ (dot and dash line), all shown in black, and $120 \mu \mathrm{M}$ (gray line), $200 \mu \mathrm{m}$ (grey dashed line), $600 \mu \mathrm{M}$ (gray dotted line), all shown in gray. Panels A-D are drawn to the same scale for clarity of comparison. The zinc concentrations in micromolar are denoted numerically.

cies present (58). The apparent $R_{G}$ values showed that C3 exhibited the strongest zinc-induced oligomerization followed by C3u, C3b, C3c, and C3d in that order (Fig. $5 \mathrm{~A}$ ). The corresponding changes in the $I(0) / c$ values were best analyzed using base-line Guinier $I(0) / c$ values from a second $Q$ fit range between 0.32 and $0.45 \mathrm{~nm}^{-1}$. The difference $\Delta$ between the two $I(0) / c$ values compensated for protein precipitation that reduced the $I(0) / c$ values (Fig. $5 B$ ). The $\Delta I(0) / c$ values showed that $\mathrm{C} 3$ exhibited the strongest oligomerization followed by C3u, C3b, C3c, and C3d in that order. These are consistent with the integrations from ultracentrifugation (Fig. 2).

The distance distribution function $P(r)$ reports on the protein shapes of the zinc-induced aggregates of the five proteins. The $P(r)$ curve gives the distances between all pairs of atoms within the macromolecule. This leads to the most frequently occurring distance $M$ from the position of the peak maximum, the maximum length $L$ from the point at which $P(r)$ becomes zero at large $Q$, and an independent calculation of the $R_{G}$ and $I(0)$ values for comparison with the above Guinier values (57). In summary, the five $P(r)$ analyses showed that $\mathrm{C} 3, \mathrm{C} 3 \mathrm{u}$, and C3b aggregated strongly with zinc concentrations of $120 \mu \mathrm{M}$ and above, whereas $\mathrm{C} 3 \mathrm{c}$ and $\mathrm{C} 3 \mathrm{~d}$ showed little significant effects.

For C3 in $2 \mu \mathrm{m}$ zinc, $M$ was $5.0 \mathrm{~nm}$, and $L$ was $16 \mathrm{~nm}$ (Fig. $6 A$ ). These values were identical with those for $\mathrm{C} 3$ without zinc (43). For 6-60 $\mu \mathrm{M}$ zinc, $M$ increased from 5.0 to $6.7 \mathrm{~nm}, L$ increased from 16 to $19 \mathrm{~nm}$, and the area under the $P(r)$ curve doubled. The changes indicated small amounts of $\mathrm{C} 3$ aggregate formation. For 120-600 $\mu \mathrm{M}$ zinc, the area under the $P(r)$ curves underwent large increases together with increases in $L$ from 16 to $50 \mathrm{~nm}$. It was concluded that aggregates of C3-zinc had formed that were more than three times larger in size than the C3 monomer.
For C3u in $2 \mu \mathrm{m}$ zinc, $M$ was $5.1 \mathrm{~nm}$, and $L$ was $16 \mathrm{~nm}$ (Fig. $6 B$ ). These values agreed closely with those of $C 3 \mathrm{u}$ without zinc (43). Up to $60 \mu \mathrm{M}$ zinc, the $P(r)$ curves remained similar with modest increases in intensity and $L$. In $120-600 \mu \mathrm{M}$ zinc, the $P(r)$ intensity for $\mathrm{C} 3 \mathrm{u}$ below $16 \mathrm{~nm}$ decreased, whereas the $P(r)$ curves became significantly broader with $L$ values that increased to about $50 \mathrm{~nm}$. The $L$ values for the $\mathrm{C} 3 \mathrm{u}$-zinc aggregates were similar to that for C3-zinc. For 120 and $200 \mu \mathrm{M}$ zinc, the reduced $P(r)$ intensities compared with those for $\mathrm{C} 3$ suggested that $\mathrm{C} 3 \mathrm{u}$ aggregated less than $\mathrm{C} 3$.

For C3b in $2 \mu \mathrm{m}$ zinc, $M$ was $4.8 \mathrm{~nm}$, and $L$ was $16 \mathrm{~nm}$ (Fig. $6 C)$, these being similar to those for $C 3$ and $C 3 u$ above. The $P(r)$ curves remained almost unchanged with increases up to $60 \mu \mathrm{M}$ zinc. Between 120 and $600 \mu \mathrm{M}$ zinc, the $P(r)$ curves changed in a similar manner to that of $\mathrm{C} 3 \mathrm{u}$, except that the intensity changes were smaller compared with those of $\mathrm{C} 3$ and $\mathrm{C} 3 \mathrm{u}$, suggesting that $\mathrm{C} 3 \mathrm{~b}$ aggregated less than $\mathrm{C} 3 \mathrm{u}$.

For C3c in $2 \mu \mathrm{M}$ zinc, $M$ was $4.5 \mathrm{~nm}$, and $L$ was $14 \mathrm{~nm}$ (Fig. $6 D)$. Unlike $\mathrm{C} 3, \mathrm{C} 3 \mathrm{u}$, and $\mathrm{C} 3 \mathrm{~b}$, the $P(r)$ curve remained almost unchanged, with only a small increase in $L$ to $18 \mathrm{~nm}$ when zinc concentration increased to $200 \mu \mathrm{M}$. In $600 \mu \mathrm{M}$ zinc, M became $5.5 \mathrm{~nm}$, and L became $22 \mathrm{~nm}$ together with slight increases in the $P(r)$ intensity. These small changes reflected little C3c aggregation between 2 and $600 \mu \mathrm{m}$ zinc.

For C3d in $2 \mu \mathrm{M}$ zinc, $M$ was $2.63 \mathrm{~nm}$, and $L$ was $6 \mathrm{~nm}$ (Fig. $6 E$; not drawn to scale). These values agreed with those of C3d without zinc (59). Between 2 and $600 \mu \mathrm{M}$ zinc, the $M$ and $L$ values and the shape of the $P(r)$ curves were almost unchanged, with only slight decreases in the $P(r)$ intensity above $120 \mu \mathrm{M}$ zinc that may result from slight $\mathrm{C} 3 \mathrm{~d}$ precipitation. These small changes also reflected little C3d aggregation between 2 and 600 $\mu \mathrm{M}$ zinc. 


\section{Zinc-induced Oligomerization of C3}

Scattering Curves of the FH-C3b-Zinc Complex-The FHC3b complex in the presence of zinc was studied by $x$-ray scattering. The Guinier fits (not shown) were performed in the same $Q$ ranges of $0.14-0.22 \mathrm{~nm}^{-1}$ for the apparent $R_{G}$ and $I(0) / c$ values and 0.32 to $0.45 \mathrm{~nm}^{-1}$ for the $I(0) / c$ base line. Each of C3b, FH and their 1:1 mixture was titrated with 2-600 $\mu \mathrm{M}$ zinc (Fig. 5, $C$ and $D$ ). On the addition of zinc, both Guinier parameters for $\mathrm{FH}$ increased rapidly in agreement with those previously seen with FH-zinc $(31,32)$. Those for C3b increased more slowly, in agreement with Fig. 5, $A$ and $B$. Those for the FH-C3b mixture increased with zinc to follow initially the results with FH-zinc. At a zinc concentration $>100 \mu \mathrm{M}$, when C3b started to bind to zinc, both the $R_{G}$ and $I(0) / c$ parameters decreased. These decreases above $100 \mu \mathrm{m}$ zinc are attributable to the formation of very large complexes of $\mathrm{FH}$ and $\mathrm{C} 3 \mathrm{~b}$ with zinc, which precipitate out of solution and no longer contribute to the scattering curves. These results are consistent with ultracentrifugation that showed that the $\mathrm{C} 3 \mathrm{~b}-\mathrm{FH}$-zinc complexes precipitated (Fig. 3, $C$ and $D$ ).

Alternative Pathway Activation Assay - To investigate whether zinc affected the complement alternative pathway, an alternative pathway hemolytic complement kit ("Experimental Procedures") was used to study the effect of zinc sulfate on complement activation in human serum. Between 0 and $100 \mu \mathrm{M}$ zinc, the activity decreased by $\sim 10 \%$ and between 100 and $5000 \mu \mathrm{M}$ zinc the activity diminished by a further $10 \%$ (Fig. 7). The results are explained by the precipitation of C3b-FH-zinc com-

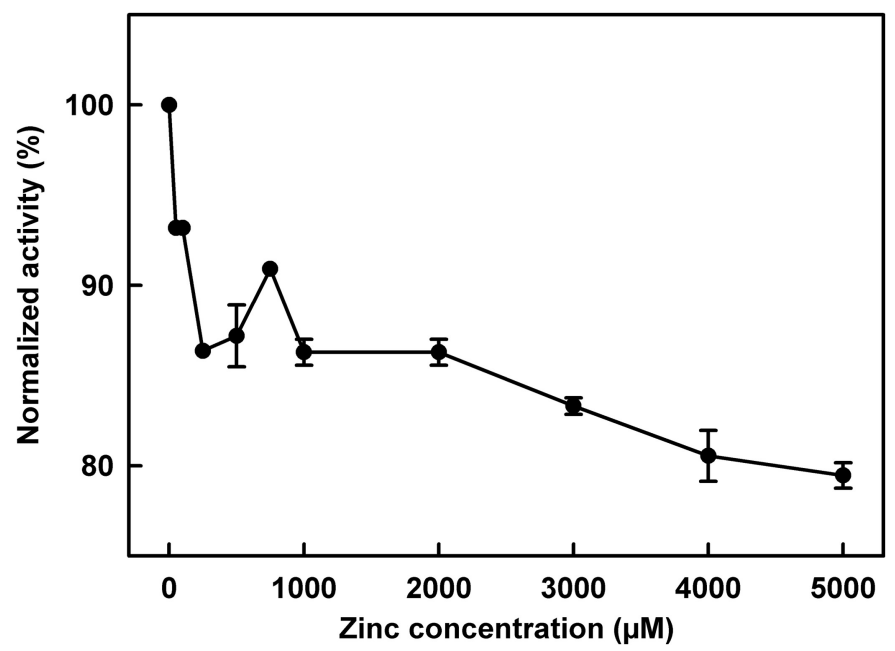

FIGURE 7. Effect of zinc on alternative pathway activation in human serum. Human serum was made 0, 100, 250, 500, 750, 1000, 2000, 3000, 4000, and $5000 \mu \mathrm{M}$ in zinc. Radial diffusion activity assays were performed and normalized to $0 \mu \mathrm{m}$. The experiment was performed in triplicate, and the means \pm S.E. of each measurement are shown. plexes, thus reducing the availability of $\mathrm{C} 3 \mathrm{~b}$ to mediate its normal inflammatory response.

Computational Zinc Binding Predictions for C3, C3u, C3b, $C 3 c$, and $C 3 d$-Zinc binding sites are generally formed from four residues that are coordinated by zinc (35). To clarify the molecular basis of $\mathrm{C} 3$ self-association with zinc, surface zinc binding sites were predicted from seven crystal and solution structures for C3, C3u, C3b, C3c, and C3d (Table 1). These were submitted to the METSITE prediction server (37). METSITE was developed using relative residue positions and does not require side-chain atoms to be present; therefore, its predictions are applicable to low resolution structures. METSITE has an estimated site sensitivity of $77 \%$ and site selectivity of $44 \%$ for zinc predictions (see Table 3 of Ref. 37). Multiple partial zinc binding sites composed of His, Glu, and Asp residues were predicted on the surface of all five structures when the neural network output residue score was $>0.7$ to correspond to strong hits (Table 1). No well defined zinc binding sites were observed, and the number of sites varied from protein to protein. If the zinc binding capacity corresponds to the number of predicted zinc binding residues per 100 residues, C3 has 2.4 unique zinc binding site residues followed by $\mathrm{C} 3 \mathrm{~b}$ at $1.8-2.9$ residues, $\mathrm{C} 3 \mathrm{u}$ at 1.8 residues, $\mathrm{C} 3 \mathrm{c}$ at 1.5 residues, and $\mathrm{C} 3 \mathrm{~d}$ with $1.0-1.3$ residues. A separate prediction for the CUB domain (which is not present in $\mathrm{C} 3 \mathrm{c}$ or $\mathrm{C} 3 \mathrm{~d}$ ) showed no zinc binding residues in CUB from $\mathrm{C} 3$, and one His residue in CUB from C3u. Overall, the predictions show that weak zinc binding to the surfaces of $\mathrm{C} 3$, $\mathrm{C} 3 \mathrm{u}$, and $\mathrm{C} 3 \mathrm{~b}$ explains their oligomer formation. The comparative Table 1 predictions were consistent with the experimental ultracentrifugation and scattering data showing strong oligomerization in C3, C3u, and C3b and weaker effects on C3c and C3d.

The front and back surfaces of the five $\mathrm{C} 3$ proteins showed that the partial zinc binding site predictions were broadly distributed (Fig. 8). Many sites were not reproducibly predicted between the five different structures; this variability is attributed to the weak zinc binding affinity. Given these moderate accuracies, zinc oligomer formation could not be assigned to specific residues in the five proteins. Nonetheless, the lack of zinc-induced oligomers for $\mathrm{C} 3 \mathrm{c}$ and $\mathrm{C} 3 \mathrm{~d}$ is attributable to insufficient totals of weak zinc sites for daisy-chaining via zinc to form oligomers (Fig. 8D). When C3c and C3d are present together in $\mathrm{C} 3, \mathrm{C} 3 \mathrm{u}$, and C3b, the zinc sites in C3c and C3d were able to pair and cross-link C3, C3u, or C3b with zinc (Fig. $8, A-C)$. The large soluble $\mathrm{C} 3$-zinc oligomers, in contrast to the precipitation seen with $\mathrm{C} 3 \mathrm{u}$-zinc and $\mathrm{C} 3 \mathrm{~b}$-zinc, are attributable

\section{TABLE 1}

METSITE predictions of zinc binding residues for the protein structures of $\mathrm{C} 3, \mathrm{C} 3 \mathrm{u}, \mathrm{C} 3 \mathrm{~b}, \mathrm{C} 3 \mathrm{c}$, and $\mathrm{C} 3 \mathrm{~d}$

The single neural network cutoff threshold was set at 0.7 in order to represent the log of the likelihood ratio scores of approximately 1.

\begin{tabular}{|c|c|c|c|c|c|}
\hline Name & PDB code & $\begin{array}{c}\text { Number of C3 } \\
\text { domains }\end{array}$ & $\begin{array}{l}\text { Number of residues } \\
\text { in the PDB file }\end{array}$ & $\begin{array}{c}\text { Unique zinc binding } \\
\text { residues predicted METSITE }>0.7\end{array}$ & $\begin{array}{l}\text { Number of unique zinc binding } \\
\text { residues per } 100 \text { residues }\end{array}$ \\
\hline C3 & $2 \mathrm{~A} 73$ & 13 & 1611 & 38 & 2.4 \\
\hline $\mathrm{C} 3 \mathrm{~b}$ & $2 \mathrm{ICF}$ & 12 & 1545 & 45 & 2.9 \\
\hline C $3 b$ & $2 \mathrm{I} 07$ & 12 & 1531 & 27 & 1.8 \\
\hline $\mathrm{C} 3 \mathrm{u}$ & 3MMQ & 13 & 1531 & 28 & 1.8 \\
\hline $\mathrm{C} 3 \mathrm{c}$ & $2 \mathrm{~A} 74$ & 10 & 1109 & 17 & 1.5 \\
\hline C $3 d$ & $1 \mathrm{C} 3 \mathrm{D}$ & 1 & 294 & 3 & 1.0 \\
\hline C $3 d$ & $1 \mathrm{GHQ}$ & 1 & 307 & 4 & 1.3 \\
\hline
\end{tabular}




\section{Zinc-induced Oligomerization of C3}
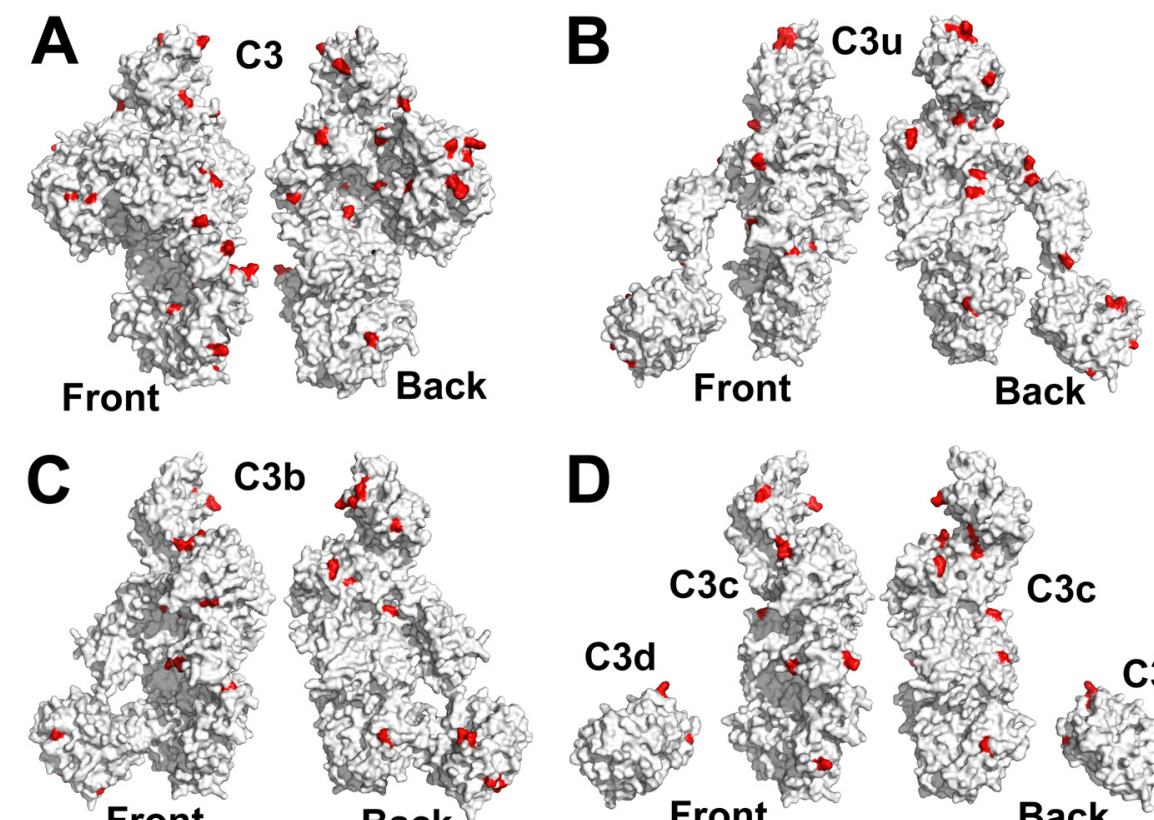

Front
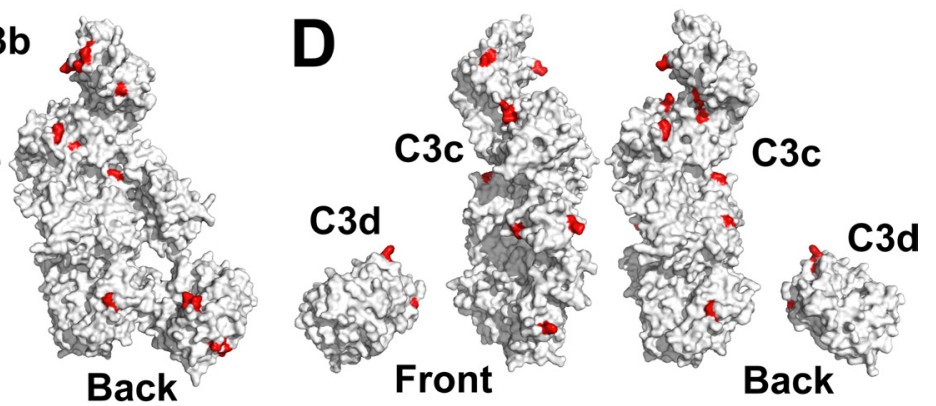

FIGURE 8. Surface view of the METSITE predictions for $\mathbf{C 3}, \mathbf{C} \mathbf{3} \mathbf{u}, \mathbf{C} \mathbf{3} \mathbf{b}, \mathbf{C} \mathbf{3}$, and $\mathbf{C} 3 \mathbf{d}$. Each structure is displayed as the front view on the left and rotated $180^{\circ}$ about the vertical axis to show the back view on the right. Residues highlighted in red represent the METSITE predictions that were registered above a neural network score of 0.7. The PDB codes are 2A73 for C3 $(A), 3 \mathrm{MMQ}$ for C3u $(B), 2107$ for C3b $(C), 2 \mathrm{A74}$ for C3c and 1C3D for C3d $(D)$.

to the different location of $\mathrm{C} 3 \mathrm{~d}$ relative to $\mathrm{C} 3 \mathrm{c}$ in the three proteins.

To test whether METSITE was able to identify partial zinc binding sites, structures with zinc located at the interface between two distinct domains were tested (35). A nerve growth factor (PDB code 1SGF) was split into two domains (chains G and $\mathrm{A}$ ) to predict the four ligands at the zinc binding site between them. In the separated domains, METSITE identified two clearly, namely His-202 and Glu-207 in domain G (scores of 0.91 and 0.98 respectively), plus a third one, Glu-51 (score of 0.55 ), but not the fourth His-58 in domain A. When the intact protein was analyzed, three of the four ligands were correctly predicted. A carbonic anhydrase (PDB code $1 \mathrm{THJ}$ ) predicted one site (chain A His-117, score 0.8 ), but two were missed (chain B His- 81 score 0.45 , and chain B His-122, no score). This outcome was the same when the intact protein or the two separate domains were analyzed. The comparisons confirm that the METSITE predictions were moderately effective at detecting weak zinc binding sites.

\section{DISCUSSION}

Our detailed study of the $\mathrm{C} 3, \mathrm{C} 3 \mathrm{u}$, and C3b interactions with zinc revealed that these proteins underwent different forms of self-association at zinc concentrations above $100 \mu \mathrm{M}$ (Table 2). With zinc, C3 formed large oligomers, C3u and C3b precipitated, and C3c and C3d showed little self-association. Most importantly, strong precipitation was observed when zinc was added to the key physiological C3b-FH complex (Fig. 9, C and $D$ ), and the activation of the complement alternative pathway was detectably inhibited by zinc. These results suggest that in inflammatory conditions the pathophysiological release of zinc at unexpectedly high concentrations into the extracellular space has the capacity to perturb the complement system and initiate protein oligomer deposition.
TABLE 2

Summary of the effect of zinc on the five forms of $\mathrm{C} 3, \mathrm{FH}$ and the C3b-FH complex

Aggregation is considered to be the sum of oligomer formation and precipitation. The outcomes of Fig. 1-6 are summarized using the following codes: A, aggregation; ma, minor aggregation; $\mathrm{O}$, oligomer; $\mathrm{P}$, precipitation; $\mathrm{mp}$, minor precipitation; MP, major precipitation; NA, not applicable.

\begin{tabular}{llllllll}
\hline Protein & Fig. 1 & Fig. 2 & Fig. 3 & Fig. 4 & Fig. 5 & Fig. 6 & Overall \\
\hline C3 & O & O & NA & A & A & O & O \\
C3u & P & P & NA & A, P & A & O, P & P \\
C3b & P & P & NA & A, P & A & O, P & P \\
C3c & & & NA & ma & A & & mp \\
C3d & & mp & NA & ma & ma & & mp \\
FH & NA & NA & O & NA & A & NA & O \\
C3b.FH & NA & NA & MP & NA & MP & NA & MP \\
\hline
\end{tabular}

Extracellular metal-induced protein aggregation is significant in several degenerative diseases such as in Alzheimer disease, amyloid and prion diseases, and age-related macular degeneration where extracellular zinc concentrations can reach high micromolar or even millimolar levels due to the release of zinc from neighboring cells $(60,61)$. The local elevation in extracellular zinc levels is likely to be the result of pathological events even though during neuronal activity, zinc is released into the synaptic cleft and is believed to reach local concentrations of $300 \mu \mathrm{M}$ (62). A number of ratiometric zinc sensors estimate the intracellular bioavailable zinc levels to be in the nanomolar to picomolar range in resting cultured cells, which can be compared with the total intracellular zinc concentration of $\sim 100 \mu \mathrm{M}$ (63). Although the extracellular bioavailable zinc levels are yet to be precisely determined, indications are that these will also be in the nanomolar to picomolar range, similar to intracellular bioavailable zinc levels. Thus bioavailable zinc levels in plasma are in a range of $20-210 \mathrm{pm}(64)$. In plasma, the total zinc level remains steady at $14.7 \mu \mathrm{M}$ even after a daily diet supplement with $80 \mathrm{mg}$ zinc in the AREDS trials (38). Most plasma zinc $(84 \%)$ is bound to human serum albumin with a $K_{D}$ 

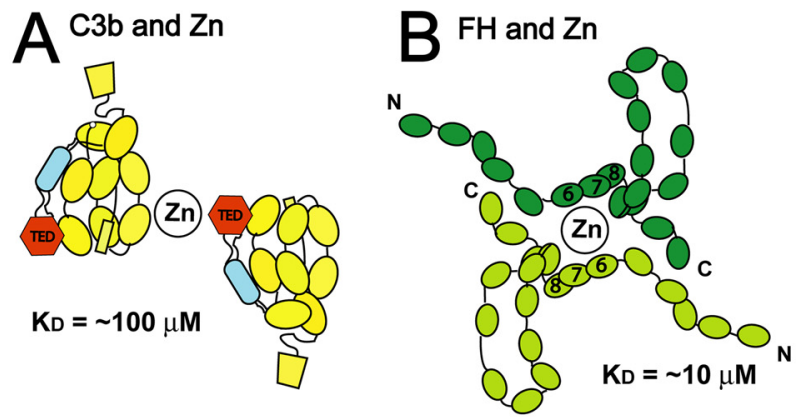

C ${ }^{\text {C3b-FH complex }}$

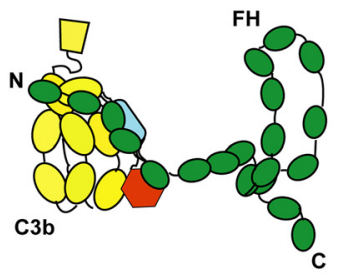

D c3b-FH complex

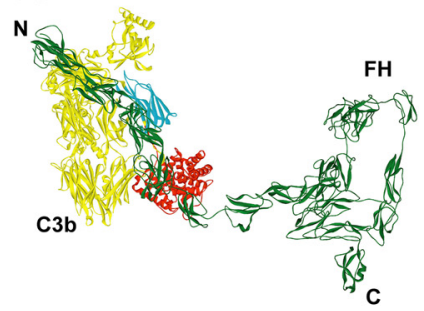

E C3b-FH oligomeric complex with Zn

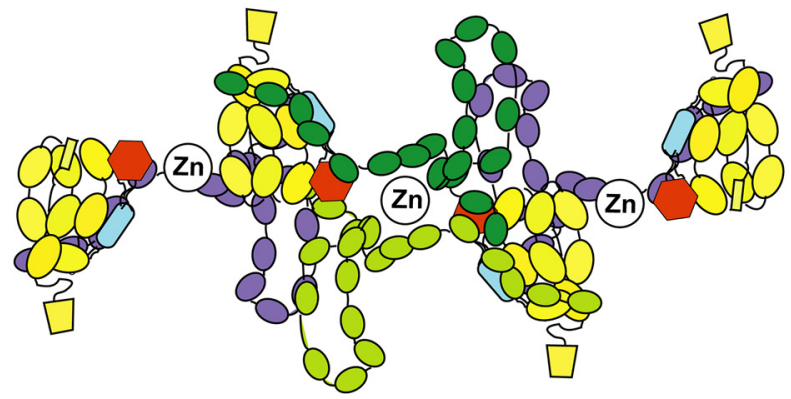

FIGURE 9. Schematic outlines of the zinc-induced oligomerization of FHzinc, C3b-zinc, and C3b-FH-zinc complexes. $A$, a putative $C 3 \mathrm{~b}$ dimer is shown in which the $\mathrm{C} 3 \mathrm{c}$ and $\mathrm{C} 3 \mathrm{~d}$ regions in yellow and red, respectively in two monomers are cross-linked by zinc. Other cross-linked forms of $\mathrm{C} 3 \mathrm{~b}$ can also be formed by the daisy-chaining of the cross-linking. $B$, a putative $\mathrm{FH}$ dimer is shown in which the SCR-6/8 domains are cross-linked by zinc. These structures can also be daisy chained to form larger oligomers. $C$ and $D$, the crystal structure of $\mathrm{C} 3 \mathrm{~b}$ with SCR-1/4 of FH is shown as a schematics form and as a molecular structure (PDB code 2WII) to which SCR-5/20 from the folded-back solution structure of FH SCR-1/20 (PDB code 3GAV; R. Nan, unpublished modeling) is added to indicate their interaction. C3b is shown in yellow (with the CUB domain in blue and the TED domain in red) and $\mathrm{FH}$ is shown in green. $E$, the formation of large aggregates of $\mathrm{C} 3 \mathrm{~b}-\mathrm{FH}$-zinc is shown. The daisy-chaining of the two dimers shown in $A$ and $B$ is accompanied by the formation of the C3b-FH complex to form an aggregated particle. Further $\mathrm{FH}$ monomers (in purple) are able to bind to the two $\mathrm{C} 3 \mathrm{~b}$ dimers, and these purple $\mathrm{FH}$ monomers are also able to bind zinc and dimerize further.

of $1 \mu \mathrm{M}$, and $\alpha 2$-macroglobulin binds $15 \%$ of plasma zinc (65). Compared with $K_{D}$ values of $\sim 100 \mu \mathrm{m}$ for C3/C3u/C3b-zinc binding and $10 \mu \mathrm{M}$ for $\mathrm{FH}$-zinc binding, human serum albumin acts as a scavenger of bioavailable zinc, and accordingly there is little risk of $\mathrm{C} 3 / \mathrm{C} 3 \mathrm{u} / \mathrm{C} 3 \mathrm{~b}$ or $\mathrm{FH}$ self-association with zinc in normal plasma conditions. The same is likely to be true for the extracellular space in a resting stage. However, pathological events may trigger the release of high concentrations of zinc locally, especially in tissues where zinc concentrations are exceptionally high such as the RPE (25).

Zinc appears to be essential for the normal function of the retina, but its exact involvement in normal and pathological functions is unclear (27). Intracellular zinc is mostly bound to proteins including metallothioneins, carbonic anhydrase, and other zinc binding proteins $(25,27,66)$. RPE cells are able to accumulate zinc after oral supplementation and retain this zinc for longer than any other tissues in the body, suggesting a special process for zinc storage and distribution in these cells (66). Zinc levels can also decrease in RPE cells under pathological conditions such as that seen in AMD (66), releasing zinc into Bruch's membrane where it could bind to proteins and induce their aggregation in vivo. These aggregated proteins then become part of sRPEds (28). We have shown that Bruch's membrane contains bioavailable zinc, especially in samples that contain substantial sRPEds, evidenced by their labeling in the presence of selective fluorescence sensors that only bind to bioavailable zinc (67). This bioavailable zinc could lead to the formation of the C3-zinc, C3u-zinc and C3b-zinc and C3b-FHzinc complexes (Fig. 8A) as well as to those for FH-zinc complexes (31). Our zinc concentrations from $100 \mu \mathrm{M}$ upwards, at which we observed oligomerization separately with each of C3, $\mathrm{C} 3 \mathrm{u}, \mathrm{C} 3 \mathrm{~b}$, and with the $\mathrm{C} 3 \mathrm{~b}-\mathrm{FH}$ complex, therefore have biomedical significance in the eye.

The zinc binding studies with $\mathrm{C} 3 / \mathrm{C} 3 \mathrm{u} / \mathrm{C} 3 \mathrm{~b}$ show that these proteins exhibit different modes for their self-association in the presence of $>100 \mu \mathrm{M}$ zinc (Figs. 2, 5, and 6). Zinc has, therefore, been useful as a probe of structural differences between these three proteins, adding to the knowledge already obtained with the crystallography of $\mathrm{C} 3$ and $\mathrm{C} 3 \mathrm{~b}$ and the constrained scattering modeling of $\mathrm{C} 3 \mathrm{u}(4,43,51)$. The more compact $\mathrm{C} 3 \mathrm{~d}-\mathrm{C} 3 \mathrm{c}$ arrangement in $\mathrm{C} 3$ promotes larger soluble oligomers with zinc, whereas the more extended C3d-C3c arrangements in $\mathrm{C} 3 \mathrm{u}$ and $\mathrm{C} 3 \mathrm{~b}$ promote greater precipitation with zinc (Fig. 9A). The fact that zinc had little effect on each of C3c or C3d suggests that both of these are involved in zinc binding only when they are together in C3, C3b, or C3u. At zinc above $10 \mu \mathrm{M}(30$, 31,32 ), strong oligomerization occurred for both the wild-type Tyr-402 and disease-related His-402 allotypes at the SCR-6/8 domains (32). Indefinite daisy-chains of cross-linked SCR-6/8 domains accounted for the large $\mathrm{FH}$ oligomers, starting from a simple dimer (Fig. 9B). Our new results showing that $\mathrm{C} 3 \mathrm{~b}$ selfassociated with zinc and that the $\mathrm{C} 3 \mathrm{~b}-\mathrm{FH}$ complex precipitated with $100 \mu \mathrm{M}$ zinc have changed this understanding. The combination of separate $\mathrm{C} 3 \mathrm{~b}$-zinc and $\mathrm{FH}$-zinc self-associations in the $\mathrm{C} 3 \mathrm{~b}-\mathrm{FH}$ complex promotes even greater amounts of oligomer formation (Fig. 9E). Each FH dimer will bind to two $\mathrm{C} 3 \mathrm{~b}$ dimers; in turn, each $\mathrm{C} 3 \mathrm{~b}$ dimer will bind to two $\mathrm{FH}$ dimers. Two separate weak zinc binding events with micromolar affinities becomes a much stronger interaction when both events occur simultaneously in different parts of the same complex (68).

$\mathrm{FH}$ is a major complement regulator and is expressed and secreted by many different cell types including the RPE (69). Factor $\mathrm{H}$ and $\mathrm{C} 3$ have been detected in retinal and RPE/choroidal tissues (70). The major physiological ligands of FH include C3b and its C3d fragment, heparan sulfate and other glycosaminoglycans, and C-reactive protein (71). All these ligands bind weakly to $\mathrm{FH}$ with micromolar affinities, as expected given the micromolar abundance of FH in serum. Thus $\mathrm{C} 3 \mathrm{~b}$ and $\mathrm{C} 3 \mathrm{~d}$ bind to FH with $K_{D}$ values of $0.6-1.6$ and $2.6 \mu \mathrm{M}$, respectively $(9,72)$, heparin binds to two sites on $\mathrm{FH}$ with $K_{D}$ values of $1-3 \mu \mathrm{M}$ (73), 
and $C$-reactive protein binds with a $K_{D}$ value of $4-15 \mu \mathrm{M}$ (74). If C3b at $1 \mathrm{mg} / \mathrm{ml}$ is mixed with $\mathrm{FH}$ at $0.8 \mathrm{mg} / \mathrm{ml}$, only $60-70 \%$ of the complex is formed with a $K_{D}$ value of $0.6-1.6 \mu \mathrm{M}$. This illustrates how complement regulatory control is achieved as the result of incomplete complex formation between its major ligands. When pathophysiological amounts of $>100 \mu \mathrm{M}$ zinc are present together with high levels of localized inflammation (when much C3b is formed), our results show that zinc will precipitate and remove the $\mathrm{C} 3 \mathrm{~b}-\mathrm{FH}$ complex and free $\mathrm{C} 3 \mathrm{~b}$. The normal mechanisms of complement control that involves multiple interactions with C3b, heparan sulfate, and C-reactive protein become perturbed (71).

In summary, we propose that during AMD-associated inflammation, two influencing factors need to be considered: (i) the release of 10-100 $\mu \mathrm{M}$ bioavailable zinc will affect the oligomerization and activity of FH (31); (ii) if zinc concentrations increase even further, C3b will also form oligomers, but more importantly any C3b-FH complexes that are formed in Bruch's membrane will precipitate in $>100 \mu \mathrm{m}$ zinc. The C3b-FH-zinc precipitates will contribute to sRPEd formation. This may explain the presence of $\mathrm{FH}, \mathrm{C} 3 \mathrm{~b}$, and other complement proteins in sRPEds (11). However, although the reduction of FH levels will promote uncontrolled inflammation, the precipitation of C3b-zinc and C3b-FH-zinc complexes will limit that. Therefore, clinically, zinc might contribute to the early and late stages of AMD in two distinct ways (75). Whether the beneficial effects of zinc supplementation (38) is related to the precipitation of C3b-FH-zinc complexes will need to be determined.

Acknowledgments-We are very grateful to Prof. Alan C. Bird and Dr. Andrew Martin for useful discussions, Dr. Daniel Buchan and Prof. David T. Jones for help with the METSITE program, Dr. Keying Li for help with initial measurements, Dr. T. Narayanan (European Synchrotron Radiation Facility, Grenoble, France) for excellent instrumental support, and Prof. Robert B. Sim for his MRC affinity columns.

\section{REFERENCES}

1. Walport, M. J. (2001) Complement. First of two parts. N. Engl. J. Med. 344, $1058-1066$

2. Law, S. K. A., and Reid, K. B. M. (1995) Complement, 2nd Ed, IRL Press at Oxford University Press, Oxford

3. Gros, P., Milder, F. J., and Janssen, B. J. (2008) Complement driven by conformational changes. Nat. Rev. Immunol. 8, 48-58

4. Janssen, B. J., Huizinga, E. G., Raaijmakers, H. C., Roos, A., Daha, M. R., Nilsson-Ekdahl, K., Nilsson, B., and Gros, P. (2005) Structures of complement component $\mathrm{C} 3$ provide insights into the function and evolution of immunity. Nature 437, 505-511

5. Wu, J., Wu, Y. Q., Ricklin, D., Janssen, B. J., Lambris, J. D., and Gros P. (2009) Structure of complement fragment C3b-factor $\mathrm{H}$ and implications for host protection by complement regulators. Nat. Immunol. 10, $728-733$

6. Morgan, H. P., Schmidt, C. Q., Guariento, M., Blaum, B. S., Gillespie, D., Herbert, A. P., Kavanagh, D., Mertens, H. D., Svergun, D. I., Johansson, C. M., Uhrín, D., Barlow, P. N., and Hannan, J. P. (2011) Structural basis for engagement by complement factor $\mathrm{H}$ of $\mathrm{C} 3 \mathrm{~b}$ on a self surface. Nat. Struct. Mol. Biol. 18, 463-470

7. Kajander, T., Lehtinen, M. J., Hyvärinen, S., Bhattacharjee, A., Leung, E., Isenman, D. E., Meri, S., Goldman, A., and Jokiranta, T. S. (2011) Dual interaction of factor $\mathrm{H}$ with $\mathrm{C} 3 \mathrm{~d}$ and glycosaminoglycans in host-nonhost discrimination by complement. Proc. Natl. Acad. Sci. U.S.A. 108, 2897-2902
8. Jokiranta, T. S., Hellwage, J., Koistinen, V., Zipfel, P. F., and Meri, S. (2000) Each of the three binding sites of factor $\mathrm{H}$ interacts with a distinct site on C3b. J. Biol. Chem. 275, 27657-27662

9. Schmidt, C. Q., Herbert, A. P., Kavanagh, D., Gandy, C., Fenton, C. J., Blaum, B. S., Lyon, M., Uhrín, D., and Barlow, P. N. (2008) A new map of glycosaminoglycan and C3b binding sites on factor H. J. Immunol. 181, $2610-2619$

10. Hageman, G. S., Luthert, P. J., Victor Chong, N. H., Johnson, L. V., Anderson, D. H., and Mullins, R. F. (2001) An integrated hypothesis that considers drusen as biomarkers of immune-mediated processes at the RPEBruch's membrane interface in aging and age-related macular degeneration. Prog. Retin. Eye Res. 20, 705-732

11. Hageman, G. S., Anderson, D. H., Johnson, L. V., Hancox, L. S., Taiber, A. J., Hardisty, L. I., Hageman, J. L., Stockman, H. A., Borchardt, J. D., Gehrs, K. M., Smith, R. J., Silvestri, G., Russell, S. R., Klaver, C. C., Barbazetto, I., Chang, S., Yannuzzi, L. A., Barile, G. R., Merriam, J. C., Smith, R. T., Olsh, A. K., Bergeron, J., Zernant, J., Merriam, J. E., Gold, B., Dean, M., and Allikmets, R. (2005) A common haplotype in the complement regulatory gene factor $\mathrm{H}(\mathrm{HF} 1 / \mathrm{CFH})$ predisposes individuals to age-related macular degeneration. Proc. Natl. Acad. Sci. U.S.A. 102, 7227-7232

12. Hageman, G. S., Hancox, L. S., Taiber, A. J., Gehrs, K. M., Anderson, D. H., Johnson, L. V., Radeke, M. J., Kavanagh, D., Richards, A., Atkinson, J., Meri, S., Bergeron, J., Zernant, J., Merriam, J., Gold, B., Allikmets, R., Dean, M., and AMD Clinical Study Group. (2006) Extended haplotypes in the complement factor $\mathrm{H}(\mathrm{CFH})$ and $\mathrm{CFH}$-related (CFHR) family of genes protect against age-related macular degeneration. Characterization, ethnic distribution, and evolutionary implications. Ann. Med. 38, 592-604.

13. Klein, R. J., Zeiss, C., Chew, E. Y., Tsai, J. Y., Sackler, R. S., Haynes, C., Henning, A. K., SanGiovanni, J. P., Mane, S. M., Mayne, S. T., Bracken, M. B., Ferris, F. L., Ott, J., Barnstable, C., and Hoh, J. (2005) Complement factor $\mathrm{H}$ polymorphism in age-related macular degeneration. Science 308, 385-389

14. Haines, J. L., Hauser, M. A., Schmidt, S., Scott, W. K., Olson, L. M., Gallins, P., Spencer, K. L., Kwan, S. Y., Noureddine, M., Gilbert, J. R., SchnetzBoutaud, N., Agarwal, A., Postel, E. A., and Pericak-Vance, M. A. (2005) Complement factor $\mathrm{H}$ variant increases the risk of age-related macular degeneration. Science 308, 419-421

15. Edwards, A. O., Ritter, R., 3rd, Abel, K. J., Manning, A., Panhuysen, C., and Farrer, L. A. (2005) Complement factor $\mathrm{H}$ polymorphism and age-related macular degeneration. Science 308, 421-424

16. Gold, B., Merriam J. E., Zernant, J., Hancox, L. S., Taiber, A. J., Gehrs, K., Cramer, K., Neel, J., Bergeron, J., Barile, G. R., Smith, R. T., AMD Genetics Clinical Study Group, Hageman, G. S., Dean, M., and Allikmets, R. (2006) Variation in factor B (BF) and complement component 2 (C2) genes is associated with age-related macular degeneration. Nat. Genet. 38, $458-462$

17. Spencer, K. L., Hauser, M. A., Olson, L. M., Schmidt, S., Scott, W. K., Gallins, P., Agarwal, A., Postel, E. A., Pericak-Vance, M. A., and Haines, J. L. (2007) Protective effect of complement factor B and complement component 2 variants in age-related macular degeneration. Hum. Mol. Genet. 16, 1986-1992

18. Yates, J. R., Sepp, T., Matharu, B. K., Khan, J. C., Thurlby, D. A., Shahid, H., Clayton, D. G., Hayward, C., Morgan, J., Wright, A. F., Armbrecht, A. M., Dhillon, B., Deary, I. J., Redmond, E., Bird, A. C., Moore, A. T., and Genetic Factors in AMD Study Group (2007) Complement C3 variant and the risk of age-related macular degeneration. N. Engl. J. Med. 357, 553-561

19. Maller, J., George, S., Purcell, S., Fagerness, J., Altshuler, D., Daly, M. J., and Seddon, J. M. (2006) Common variation in three genes, including a noncoding variant in $\mathrm{CFH}$, strongly influences risk of age-related macular degeneration. Nat. Genet. 38, 1055-1059

20. Bird, A. C. (1992) Bruch's membrane changes with age. Br. J. Ophthalmol. 76, $166-168$

21. Bird, A. C., Bressler, N. M., Bressler, S. B., Chisholm, I. H., Coscas, G., Davis, M. D., de Jong, P. T., Klaver, C. C., Klein, B. E., and Klein, R. (1995) An international classification and grading system for age-related maculopathy and age-related macular degeneration. Surv. Ophthalmol. 39, 367-374

22. Guymer, R., and Bird, A. C. (1998) Bruch's membrane, drusen, and age- 


\section{Zinc-induced Oligomerization of $\mathrm{C} 3$}

related macular degeneration. in The retinal pigment epithelium (Marmor, M., and Wolfensberger, T., eds) pp. 693-705, Oxford University Press, Oxford

23. Crabb, J. W., Miyagi, M., Gu, X., Shadrach, K., West, K. A., Sakaguchi, H., Kamei, M., Hasan, A., Yan, L., Rayborn, M. E., Salomon, R. G., and Hollyfield, J. G. (2002) Drusen proteome analysis. An approach to the etiology of age-related macular degeneration. Proc. Natl. Acad. Sci. U.S.A. 99, 14682-14687

24. Bok, D. (2005) Evidence for an inflammatory process in age-related macular degeneration gains new support. Proc. Natl. Acad. Sci. U.S.A. 102, 7053-7054

25. Galin, M. A., Nano, H. D., and Hall, T. (1962) Ocular zinc concentration. Invest. Ophthalmol. 1, 142-148

26. Grahn, B. H., Paterson, P. G., Gottschall-Pass, K. T., and Zhang Z. (2001) Zinc and the eye. J. Am. Coll. Nutr. 20, 106-118

27. Ugarte, M., and Osborne, N. N. (2001) Zinc in the retina. Prog. Neurobiol. 64, 219-249

28. Lengyel, I., Flinn, J. M., Peto, T., Linkous, D. H., Cano, K., Bird, A. C., Lanzirotti, A., Frederickson, C. J., and van Kuijk, F. J. (2007) High concentration of zinc in sub-retinal pigment epithelial deposits. Exp. Eye Res. 84, 772-780

29. Crossley, L. G., and Porter, R. R. (1980) Purification of the human complement control protein C3b inactivator. Biochem. J. 191, 173-182

30. Perkins, S. J., Nealis, A. S., and Sim, R. B. (1991) Oligomeric domain structure of human complement factor $\mathrm{H}$ by X-ray and neutron solution scattering. Biochemistry 30, 2847-2857

31. Nan, R., Gor, J., Lengyel, I., and Perkins, S. J. (2008) Uncontrolled zinc- and copper-induced oligomerisation of the human complement regulator factor $\mathrm{H}$ and its possible implications for function and disease. J. Mol. Biol. 384, 1341-1352

32. Nan, R., Farabella, I., Schumacher, F. F., Miller, A., Gor, J., Martin, A. C., Jones, D. T., Lengyel, I., and Perkins, S. J. (2011) Zinc binding to the Tyr402 and His-402 allotypes of complement factor $\mathrm{H}$. Possible implications for age-related macular degeneration. J. Mol. Biol. 408, 714-735

33. Tsiftsoglou, S. A., and Sim, R. B. (2004) Human complement factor I does not require cofactors for cleavage of synthetic substrates. J. Immunol. 173, 367-375

34. Blom, A. M., Kask, L., Ramesh, B., and Hillarp, A. (2003) Effects of zinc on factor I cofactor activity of C4b-binding protein and factor $\mathrm{H}$. Arch. Biochem. Biophys. 418, 108-118

35. Auld, D. S. (2001) Zinc coordination sphere in biochemical zinc sites. Biometals 14, 271-313

36. Perkins, S. J., Nan, R., Li, K., Khan, S., and Abe, Y. (2011) Analytical ultracentrifugation combined with X-ray and neutron scattering. Experiment and modeling. Modern analytical ultracentrifugation methods. Methods 54, 181-199

37. Sodhi, J. S., Bryson, K., McGuffin, L. J., Ward, J. J., Wernisch, L., and Jones, D. T. (2004) Predicting metal-binding site residues in low-resolution structural models. J. Mol. Biol. 342, 307-320

38. Age-Related Eye Disease Study Research Group (2001) A randomized, placebo-controlled, clinical trial of high-dose supplementation with vitamins $\mathrm{C}$ and $\mathrm{E}$, beta carotene, and zinc for age-related macular degeneration and vision loss. AREDS report no. 8. Arch. Ophthalmol. 119, $1417-1436$

39. Klein, M. L., Francis, P. J., Rosner, B., Reynolds, R., Hamon, S. C., Schultz, D. W., Ott, J., and Seddon, J. M. (2008) CFH and LOC387715/ARMS2 genotypes and treatment with antioxidants and zinc for age-related macular degeneration. Ophthalmology 115, 1019-1025

40. Dodds, A. W. (1993) Small-scale preparation of complement components C3 and C4. Methods Enzymol. 223, 46-61

41. Guthridge, J. M., Rakstang, J. K., Young, K. A., Hinshelwood, J., Aslam, M., Robertson, A., Gipson, M. G., Sarrias, M.-R., Moore, W. T., Meagher, M., Karp, D., Lambris, J. D., Perkins, S. J., and Holers, V. M. (2001) Structural studies in solution of the recombinant $\mathrm{N}$-terminal pair of short consensus/ complement repeat domains of complement receptor type 2 (CR2/CD21) and its interaction with its ligand C3dg. Biochemistry 40, 5931-5941

42. Perkins, S. J. (1986) Protein volumes and hydration effects. The calculation of partial specific volumes, neutron scattering match points, and 280-nm absorption coefficients for proteins and glycoproteins from amino acid sequences. Eur. J. Biochem. 157, 169-180

43. Li, K., Gor, J., and Perkins, S. J. (2010) Self-association and domain rearrangements between complement $\mathrm{C} 3$ and $\mathrm{C} 3 \mathrm{u}$ provide insight into the activation mechanism of C3. Biochem. J. 431, 63-72

44. Schuck, P. (1998) Sedimentation analysis of non-interacting and self-associating solutes using numerical solutions to the Lamm equation. Biophys. J. 75, 1503-1512

45. Schuck, P. (2000) Size-distribution analysis of macromolecules by sedimentation velocity ultracentrifugation and Lamm equation modeling. Biophys. J. 78, 1606-1619

46. Okemefuna, A. I., Gilbert, H. E., Griggs, K. M., Ormsby, R. J., Gordon, D. L., and Perkins, S. J. (2008) The regulatory SCR-1/5 and cell-surface binding SCR-16/20 fragments of Factor $\mathrm{H}$ reveal partially folded-back solution structures and different self-associative properties. J. Mol. Biol. 375, $80-101$

47. Narayanan, T., Diat, O., and Bosecke, P. (2001) SAXS and USAXS on the high brilliance beamline at the ESRF. Nucl. Instrum. Methods Phys. Res. A. 467-468, 1005-1009

48. Fernando, A. N., Furtado, P. B., Clark, S. J., Gilbert, H. E., Day, A. J., Sim, R. B., and Perkins, S. J. (2007) Associative and structural properties of the region of complement Factor $\mathrm{H}$ encompassing the Tyr402His diseaserelated polymorphism and its interactions with heparin. J. Mol. Biol. 368, $564-581$

49. Glatter, O., and Kratky, O. (Editors) (1982) Small Angle X-ray Scattering. pp. 17-51, Academic Press, Inc., New York

50. Semenyuk, A. V., and Svergun, D. I. (1991) GNOM. A program package for small-angle scattering data-processing. J. Appl. Crystallogr. 24, 537-540

51. Janssen, B. J., Christodoulidou, A., McCarthy, A., Lambris, J. D., and Gros, P. (2006) Structure of C3b reveals conformational changes that underlie complement activity. Nature 444, 213-216

52. Wiesmann, C., Katschke, K. J., Yin, J., Helmy, K. Y., Steffek, M., Fairbrother, W. J., McCallum, S. A., Embuscado, L., DeForge, L., Hass, P. E., and van Lookeren Campagne, M. (2006) Structure of C3b in complex with CRIg gives insights into regulation of complement activation. Nature 444, 217-220

53. Nagar, B., Jones, R. G., Diefenbach, R. J., Isenman, D. E., and Rini, J. M. (1998) X-ray crystal structure of C3d. A C3 fragment and ligand for complement receptor 2. Science 280, 1277-1281

54. Szakonyi, G., Guthridge, J. M., Li, D., Young, K., Holers, V. M., and Chen, X. S. (2001) Structure of complement receptor 2 in complex with its C3d ligand. Science 292, 1725-1728

55. Cole, J. L., Lary, J. W., P Moody, T., and Laue, T. M. (2008) Analytical ultracentrifugation. Sedimentation velocity and sedimentation equilibrium. Methods Cell Biol. 84, 143-179

56. Li, K., Okemefuna, A. I., Gor, J., Hannan, J. P., Asokan, R., Holers, V. M., and Perkins, S. J. (2008) Solution structure of the complex formed between human complement C3d and full-lengthcomplement receptor Type 2. J. Mol. Biol. 384, 137-150

57. Perkins, S. J., Okemefuna, A. I., Fernando, A. N., Bonner, A., Gilbert, H. E., and Furtado, P. B. (2008) X-ray and neutron scattering data and their constrained molecular modelling. Methods Cell Biol. 84, 375-423

58. Guinier, A., and Fournet, G. (1955) Small Angle Scattering of X-rays, pp. 126 -160, John Wiley \& Sons, Inc., New York

59. Gilbert, H. E., Eaton, J. T., Hannan, J. P., Holers, V. M., and Perkins, S. J. (2005) Solution structure of the complex between CR2 SCR 1-2 and C3d of human complement. An X-ray scattering and sedimentation modelling study. J. Mol. Biol. 346, 859-873

60. Maret, W., and Li, Y. (2009) Coordination dynamics of zinc in proteins. Chem. Rev. 109, 4682-4707

61. Craddock, T. J., Tuszynski, J. A., Chopra, D., Casey, N., Goldstein, L. E., Hameroff, S. R., and Tanzi, R. E. (2012) The zinc dyshomeostasis hypothesis of Alzheimer's disease. PLoS ONE 7, e33552

62. Howell, G. A., Welch, M. G., and Frederickson, C. J. (1984) Stimulationinduced. Uptake and release of zinc in hippocampal slices. Nature 308, $736-738$

63. Krezel, A., and Maret, W. (2006) Zinc-buffering capacity of a eukaryotic cell at physiological pZn. J. Biol. Inorg. Chem. 11, 1049-1062 


\section{Zinc-induced Oligomerization of $\mathrm{C} 3$}

64. Colvin, R. A., Holmes, W. R., Fontaine, C. P., and Maret, W. (2010) Cytosolic zinc buffering and muffling. Their role in intracellular zinc homeostasis. Metallomics 2, 306-317

65. Haase, H., and Maret, W. (2010) in Cellular and Molecular Biology of Metals (Zalups, R., and Koropatnick, J., eds) pp. 179-210, Taylor and Francis, London

66. Newsome, D. A., Oliver, P. D., Deupree, D. M., Miceli, M. V., and Diamond, J. G. (1992) Zinc uptake by primate retinal pigment epithelium and choroid. Curr. Eye Res. 11, 213-217

67. Nolan, E. M., and Lippard, S. J. (2009) Small-molecule fluorescent sensors for investigating zinc metalloneurochemistry. Acc. Chem. Res. 42, 193-203

68. Jencks, W. P. (1981) On the attribution and additivity of binding energies. Proc. Natl. Acad. Sci. U.S.A. 78, 4046-4050

69. An, E., Lu, X., Flippin, J., Devaney, J. M., Halligan, B., Hoffman, E. P., Hoffman, E., Strunnikova, N., Csaky, K., and Hathout, Y. (2006) Secreted proteome profiling in human RPE cell cultures derived from donors with age related macular degeneration and age matched healthy donors. J. Proteome Res. 5, 2599-2610
70. Luo, C., Chen, M., and Xu, H. (2011) Complement gene expression and regulation in mouse retina and retinal pigment epithelium/choroid. Mol. Vis. 17, 1588-1597

71. Perkins, S. J., Nan, R., Li, K., Khan, S., and Miller, A. (2012) Complement factor $\mathrm{H}$-ligand interactions. Self-association, multivalency, and dissociation constants. Immunobiology 217, 281-297

72. Okemefuna, A. I., Nan, R., Gor, J., and Perkins, S. J. (2009) Electrostatic interactions contribute to the folded-back conformation of wild-type human Factor H. J. Mol. Biol. 391, 98-118

73. Khan, S., Nan, R., Gor, J., Mulloy, B., and Perkins, S. J. (2012) Bivalent and co-operative binding of complement Factor $\mathrm{H}$ to heparan sulphate and heparin. Biochem. J. 444, 417-428

74. Okemefuna, A. I., Nan, R., Miller, A., Gor, J., and Perkins, S. J. (2010) Complement Factor $\mathrm{H}$ binds at two independent sites to $\mathrm{C}$-reactive protein in acute-phase concentrations. J. Biol. Chem. 285, 1053-1065

75. Lengyel, I., and Peto, T. (2008) Cure or cause. The opposing roles for zinc in age-related macular degeneration. Expert Rev. Ophthalmol. 3, $1-4$ 